\title{
Transport of zinc ions in the hyporheic zone: Experiments and simulations
}

Guangqiu Jin ${ }^{1}$, Zhongtian Zhang ${ }^{1}$, Ruzhong $\mathrm{Li}^{2}$, Chen Chen ${ }^{1}$, Hongwu Tang ${ }^{1, \#, \text { Ling }}$ $\mathrm{Li}^{3}$, D. A. Barry

${ }^{1}$ State Key Laboratory of Hydrology-Water Resources and Hydraulic Engineering, Hohai University, Nanjing, China

Emails: jingq@hhu.edu.cn, zhongtian_zhang@163.com, hwtang@hhu.edu.cn, chenchenhhu@163.com

${ }^{2}$ School of Resources and Environmental Engineering, Hefei University of Technology, Hefei 230009, China

Emails:Lrz1970@163.com

${ }^{3}$ School of Engineering, Westlake University, Hangzhou, China

Email: liling@westlake.edu.cn

${ }^{4}$ Laboratoire de technologie écologique, Institut d'ingénierie de l'environnement, Faculté de l'environnement naturel, architectural et construit (ENAC), Ecole Polytechnique Fédérale de Lausanne (EPFL), Station 2, 1015 Lausanne, Switzerland Email: andrew.barry@epfl.ch

\#Author to whom all correspondence should be addressed. Tel: +86 (25) 8378-6662. Fax: +86 (25) 8373-5375 


\section{Abstract}

Large amounts of toxic metals are discharged into rivers and lakes, but little is known about the

21 factors that drive the adsorption and transformation of these metals in the hyporheic zone and the

22 exchange flux across the sediment-water interface. To better understand transport and

23 transformation of metal ions in the hyporheic zone, flume experiments and numerical simulations

24 were performed in a streambed with periodic bedforms using zinc ions. Compared to non-adsorbing

25 contaminant, the results show that adsorption leads to a more rapid decrease in the concentration of

$26 \mathrm{Zn}^{2+}$ in the overlying water, and a lower final concentration is reached. The mass of adsorbed ions is

27 several times higher than that of free ions in the bedform's water phase. Indeed, metal adsorption is

28 in the shallow layer of the streambed. Although this prevents heavy metal groundwater

29 contamination, the same cannot be said of shallow layer of the hyporheic zone. Knowledge of the

30 migration and transformation of metal ions in the hyporheic zone provides insights pertinent to the

31 restoration of polluted rivers.

32 Keywords: Metal ions; Zinc ions; Hyporheic exchange; Adsorption; Flume experiment; Numerical 33 simulation 


\section{Introduction}

Metals have been used by humans for thousands of years [1], and a large amount of metals are discharged from domestic [2,3] and industrial sources [4-6] into rivers and lakes [7,8]. It is noted 37 that some of these metals, especially heavy metals [9-11], are driven by hydrodynamic forces $[7,8,12]$. They are transported and retained in aquatic and hyporheic ecosystems [13] for long

periods as they are difficult to degrade $[14,15]$. These toxic metals may cause protein denaturation, enzyme inactivation and DNA damage $[16,17]$ and thus pose a threat to aquatic ecosystems $[18,19]$ and humans [20].

The hyporheic zone provides an area for surface water-groundwater exchange $[21,22]$, transport and transformation of nutrients and trace metals $[23,24]$ and is a habitat for aquatic biota $[25,26]$. It can act as a physical, chemical and biological filter to transform pollutants [27]. Notably, metallic pollutants are likely to be released back to the overlying water from the hyporheic zone under hydrodynamic forcing, thereby causing secondary pollution $[28,29]$.

Manganese and iron oxides attached to sediments can increase the removal rate of trace metals and heavy metals as they may provide additional sites for adsorption [30,31]. Fuller and Bargar [32] investigated the distribution of zinc ( $\mathrm{Zn})$ and manganese oxides in Pinal Creek, Arizona, by field sampling and found attenuation of zinc is affected by biogenic manganese oxides in hyporheic zone. Peña et al. [33] found in their bacterial culture experiments that Ni could be effectively scavenged by bacterial biomass-birnessite assemblages. However, they mainly focused on the mechanism of metal adsorption-desorption rather than their transport in the hyporheic zone. Ren and Packman [34,35] conducted flume experiments to investigate the stream-streambed interface flux of dissolved $\mathrm{Zn}, \mathrm{Cu}$ and phosphate in the presence of colloids, and found that adsorption had a 
significant effect on metal transport in the hyporheic zone. They examined the exchange rate of ions between stream and streambed, but did not consider the distribution pattern of ions in the streambed.

Palumbo-Roe et al. $[36,37]$ investigated the sources of metals in the hyporheic zone and found that

poor connectivity of the hyporheic zone, but the transport pattern of metals in hyporheic zone remains unclear. Some previous studies also provide valuable insights into factors driving the adsorption and transformation of metals, and found that metal sulfide deposits and bacteriogenic sulfides in river sediments enhance the adsorption of heavy metals, while high sediment permeability prevents accumulation of heavy metals in riverbeds [38]. The transformation of metals in the hyporheic zone is influenced by water movement, permeability, substrate particle size, resident biota, and the physiochemical features of the overlying stream and adjacent aquifers [39]. In spite of this, these previous studies concentrated more on the surface water and interface exchange in rivers, but not on the inner area of the hyporheic zone.

In order to better understand transport and fate of metal ions in the hyporheic zone, flume experiments and simulations are investigated here. We describe experiments with flow over a streambed with periodic bedforms, which induces interactions between the bed and the overlying water, i.e., the flow/bedform interaction generates hydraulic gradients that drive pore water flow in the hyporheic zone (Fig. 1a, b). $\mathrm{Zn}^{2+}$ ions are used as the transported metal within the overland flow $74[34,35]$, while the bedforms are triangular, similar to previous experiments $[40,41,42]$. Given that the transport of metal ions in the streambed is determined by pore water flow and adsorption (Fig. 1c), the main purpose of this study is to investigate 1) how does adsorption affect the transport of metal ions in the streambed? and 2) what are the transport and distribution characteristics of metals 
in the hyporheic zone?

\section{Laboratory experiments}

\subsection{Flume and sand}

Experiments were conducted in an indoor recirculating flume for physical modeling of a river with uniform triangular bedforms (Fig. 1a). The wall of the flume is made of transparent glass, permitting imaging of the experiments. The effective length of the sand bed is about $10 \mathrm{~m}$; its height varied from $12.0 \mathrm{~cm}$ at the trough to $14.0 \mathrm{~cm}$ at the crest (Fig. 1b, Table 1); the average overlying water depth was $8.22 \mathrm{~cm}$ (Table 1). A transducer was installed at the tail end of the flume for monitoring the temperature, conductivity, $\mathrm{pH}$ and salinity of the overlying water.

The bedform was made of silica sand from the Yangtze River, which was sieved to $0.25-0.60$ $\mathrm{mm}$ with a median grain size of $d=0.387 \mathrm{~mm}$. The bulk porosity $(\theta)$ was measured as 0.33 with the water evaporation method. The saturated hydraulic conductivity was $K=8.84 \times 10^{-4} \mathrm{~m} \mathrm{~s}^{-1}$, determined using the constant-head method. Both properties were assumed to remain constant during the experiments [43]. Before the experiments, the sand was washed to remove metal ions, oxides, organic matter and other impurities [44]. The sand washing steps were: 1) Washing with deionized water four times, 45 mins each time; 2) washing with an acidic solution at $\mathrm{pH} 3.5$ for 8-9 $\mathrm{h} ; 3$ ) repeat the washing in step 1 three more times; 4) repeat step 2 with a solution at $\mathrm{pH} 10.5 ; 5)$ repeat step 1 three times. In the experiments, the $\mathrm{pH}$ of the flume effluent was 6.8 .

\subsection{Experiments and measurements of $\mathrm{Zn}^{2+}$ concentrations}

The washed sand was packed into the flume, then the bedform stability was checked by overland flow. Subsequently, $\mathrm{NaCl}$ was added to the overlying water to give an initial ionic strength of $7.5 \mathrm{mM}$ based on previous work [44]. Buffer $\left(\mathrm{NaHCO}_{3}\right.$ solution) was added to maintain the $\mathrm{pH}$ 
around 7 in the flume surface water. Finally, $\mathrm{ZnCl}_{2}$ solution was uniformly added to the flow. The replace evaporated water. The $\mathrm{pH}$ was monitored periodically and maintained using buffer solutions.

During the initial $30 \mathrm{~min}$, the overlying water was simultaneously extracted from three different positions (entry, midpoint, exit) of the flume. After $30 \mathrm{~min}$, it was extracted only at the exit of the flume because the solute was almost uniform in the overlying water [44]. In addition, $0.25 \mathrm{~mL}$ of pore water was extracted from sampling points (Fig. 1b) using Hamilton (Switzerland) microsamplers (outer diameter: $0.72 \mathrm{~mm}$; inner diameter: $0.15 \mathrm{~mm}$; length: $51 \mathrm{~mm}$ ). Then, samples were placed in a 4-mL glass bottle and diluted with $2 \mathrm{~mL}$ of deionized water. The $\mathrm{NaCl}$ samples were measured in situ using electrical conductivity (EC) assuming a linear relationship between concentration and EC [42]. For zinc, sample vials were sealed and refrigerated for subsequent measurement using ICP-MS.

\section{Numerical simulations, adsorption models and coefficients}

Stream water flow, pore water flow, and reactive and nonreactive solute transport in the streambed were simulated based on one-way sequential couplin [41,45-47]. Stream water flow was computed using the 2D CFD package, FLUENT, based on the Reynolds-Averaged Navier-Stokes equations together with the $k-\omega$ turbulence closure scheme [44]. The predicted pressures at the bed surface were used as boundary conditions in a 2D COMSOL-based model for simulation of pore water flow and reactive and nonreactive solute transport in the streambed. The pore water flow was modeled using Darcy's Law and the continuity equation for incompressible flow in a nondeformable medium based on boundary conditions described by Jin et al. [44]. Finally, the transport 
of reactive and nonreactive solutes was simulated based on the pore water flow field. The mesh selection is discussed in Section S1 (S refers to Supplementary Material).

\subsection{Pore water flow}

COMSOL Multiphysics was used to model the flow and solute transport in the bed. The pore

water flow is governed by the combination of Darcy's Law and the continuity equation for incompressible flow in a non-deformable medium, and thus the groundwater flow can be described as (constant fluid density assumed):

$$
\begin{gathered}
\frac{\partial u_{i}}{\partial x_{i}}=0 \\
u_{i}=-\frac{K}{\theta} \frac{\partial h}{\partial x_{i}}
\end{gathered}
$$

where $\theta(-)$ is the volumetric porosity, $K\left(\mathrm{~m} \mathrm{~s}^{-1}\right)$ is the hydraulic conductivity, $u_{i}(i=1,2)$ is the pore water flow velocity component in the $x_{i}(i=1,2)$ direction and $h$ is the hydraulic head.

Simulation parameters are shown in Table 1 and boundary condition are shown in Fig. S2a.

\subsection{Mass transport}

The linear adsorption equilibrium adsorption [48], were considered in the simulation. The linear isothermal adsorption equation is described as [34],

$$
S=K_{a d} C
$$

where $S\left(\mathrm{~kg} \mathrm{~kg}^{-1}\right)$ is the adsorbed mass per bulk mass, $C\left(\mathrm{~kg} \mathrm{~m}^{-3}\right)$ is the equilibrium concentration of contaminants in the pore water, $K_{a d}\left(\mathrm{~m}^{3} \mathrm{~kg}^{-1}\right)$ is the equilibrium constant for linear adsorption. The linear adsorption model satisfactorily describes this experiment (Section 4).

Using Eq. 3, the zinc ion transport is given by:

$$
\left(1+\frac{\rho_{b}}{\theta} K_{a d}\right) \frac{\partial C}{\partial t}=\frac{\partial}{\partial x_{i}}\left(D_{i j} \frac{\partial C}{\partial x_{j}}-u_{i} C\right)
$$


where $\rho_{b}\left(\mathrm{~kg} \mathrm{~m}^{-3}\right)$ is the bulk density and $D_{i j}\left(\mathrm{~m}^{2} \mathrm{~s}^{-1}\right)$ is the 2D dispersion coefficient tensor:

$$
D_{i j}=\left(\alpha_{T}|u|+D_{e}\right) \delta_{i j}+\left(\alpha_{L}-\alpha_{T}\right) u_{i} u_{j} /|u|
$$

Here, $\alpha_{L}$ and $\alpha_{T}$ are the longitudinal and transverse dispersivities, respectively; $|u|=\sqrt{u_{1}^{2}+u_{2}^{2}}$ is the magnitude of the pore water flow velocity; and $D_{e}$ is the effective molecular diffusion coefficient.

\subsection{Boundary conditions for mass transport}

The boundary conditions for metal ion transport were set as follows (Fig. S2): (1) periodic conditions with $C\left(0, x_{2}, t\right)=C\left(L, x_{2}, t\right)$ and $\partial C\left(0, x_{2}, t\right) / \partial x_{2}=\partial C\left(L, x_{2}, t\right) / \partial x_{2}$ were imposed on the lateral boundaries $\left(x_{1}=0, L\right)$ of the domain. Note that only one bedform was simulated as the processes and conditions for different bedforms were assumed to behave similarly; (2) a no-flux condition was imposed on the bottom boundary of the domain, giving a zero concentration gradient $\partial C /\left.\partial x_{2}\right|_{x_{2}=0}=0[49,50]$; and (3) the following boundary conditions were imposed along the sediment-water interface:

$$
\begin{cases}C=C_{t} & \mathbf{n} \bullet \mathbf{u} \geq 0 \\ \frac{\partial C}{\partial \mathbf{n}}=0 & \mathbf{n} \bullet \mathbf{u}<0\end{cases}
$$

where $\mathbf{n}$ is the unit vector normal to the interface (pointing inward), $\mathbf{u}$ is the flow velocity vector of metal ions, and $C_{t}\left(\mathrm{~kg} \mathrm{~m}^{-3}\right)$ is the concentration of metal ions in the overlying water at time $t$. The overlying water in our experiments was well mixed and hence a spatially uniform concentration was assumed along the flume. However, $C_{t}$ varies with time due to mass exchange between the overlying water and the bed:

$$
C_{t}=\frac{C_{0} V_{o}-B \iint\left(\theta C\left(x_{1}, x_{2}, t\right)+\rho_{b} S\left(x_{1}, x_{2}, t\right)\right) d A}{V_{o}},
$$

where $V_{o}\left(\mathrm{~m}^{3}\right)$ is the total water volume in the flume system excluding $V_{p}$ (pore water in the 
streambed), $C\left(x_{1}, x_{2}, t\right)$ and $S\left(x_{1}, x_{2}, t\right)$ are, respectively, the simulated concentrations of metal ions

in the pore water and adsorbed metal ions in the sand at location $\left(x_{1}, x_{2}\right)$ and time $t, B(\mathrm{~m})$ is the width of the flume, and $A\left(\mathrm{~m}^{2}\right)$ is the area (on the $x_{1}-x_{2}$ plane shown in Fig. S2) of the bed in the

flume. The integral in Eq. 7 gives the mass of ions retained in the bed.

\subsection{Calibration of equilibrium constant $\left(K_{a d}\right)$}

Batch adsorption experiments were conducted to obtain the equilibrium constant for linear adsorption $\left(K_{a d}\right)$. First, $150 \mathrm{~g}$ of dried sand was added to $150 \mathrm{~mL}$ of $7.5 \mathrm{mM} \mathrm{NaCl}$ solution, then $\mathrm{Zn}^{2+}$ (at various initial concentrations in the range $0.010-0.040 \mathrm{mM}$ ) was added keeping the $\mathrm{pH}$ (range 2-9) fixed $\left(\mathrm{NaHCO}_{3}\right.$ buffer). The resulting mixtures were shaken for $48 \mathrm{~h}$ in order to reach equilibrium. The adsorption time of $\mathrm{Zn}^{2+}$ ions was determined before the batch adsorption experiments (Fig. 2a).

Exchange of $\mathrm{Zn}^{2+}$ with the soil is assumed to follow the reaction [34]:

$$
\mathrm{SiOH}+\mathrm{Zn}^{2+} \leftrightarrow \mathrm{SiOZn}^{+}+\mathrm{H}^{+}
$$

where $\mathrm{SiOH}$ is the surface hydroxyl species of silica sand, and $\mathrm{SiOHZn}^{+}$are adsorbed phase $\mathrm{Zn}^{2+}$ ions. The equilibrium constant $\left(K_{Z n}\right)$ of this reaction is [51]:

$$
K_{Z n}=\frac{\left[\mathrm{SiOZn}^{+}\right]\left[\mathrm{H}^{+}\right]}{[\mathrm{SiOH}]\left[\mathrm{Zn}^{2+}\right]} \exp \left|\frac{F \psi_{0}}{R_{0} T}\right|
$$

where $F\left(96493.5 \mathrm{~J} \mathrm{~V}^{-1} \mathrm{eq}^{-1}\right)$ is the Faraday constant, $\Psi_{0}(\mathrm{~V})$ is the potential on the surface of silica sand, $R_{0}\left(8.3147 \mathrm{~J} \mathrm{~mol}^{-1} \mathrm{~K}^{-1}\right)$ is the gas constant, $T\left({ }^{\circ} \mathrm{K}\right)$ is the temperature and the brackets indicate activity. As $[\mathrm{SiOH}]=1$, Eq. 9 can be converted into (base 10 logarithm):

$$
\log \left(K_{Z n}\right)-\log \left(\exp \left|\frac{F \psi_{0}}{R_{0} T}\right|\right)+\mathrm{pH}=\log \left[\mathrm{SiOZn}^{+}\right]-\log \left[\mathrm{Zn}^{2+}\right]
$$


Later, we use $\varphi=\log \left(K_{Z n}\right)-\log \left(\exp \left|\frac{F \psi_{0}}{R_{0} T}\right|\right)$ in this expression.

The adsorbed proportion $\left(P_{S T}\right)$ is defined as the ratio of adsorbed mass to the total mass

(assuming activities can be replaced by concentrations):

$$
P_{S T}=\frac{\left[\mathrm{SiOZn}^{+}\right]}{\left[\mathrm{SiOZn}^{+}\right]+\left[\mathrm{Zn}^{2+}\right]}
$$

Using Eq. 10 and approximating activities by molarity reduces Eq. 11 to:

$$
P_{S T}=\left(1+10^{-\varphi-p H}\right)^{-1}
$$

The fits of this equation to the measured adsorption data are found in Fig. 2b, which involve fitting $\varphi$. For the conditions of the flume experiment $\left(\varphi=-6.003, C_{M 0}=0.036 \mathrm{mM}, \mathrm{pH}=6.8\right)$, the adsorbed proportion $P_{S T}=0.8622$. The equilibrium constant for linear adsorption is then found using:

$$
K_{a d}=\frac{\theta \quad P_{S T}}{\rho_{b} 1-P_{S T}}
$$

\section{Results and Discussion}

The concentrations of $\mathrm{NaCl}$ and $\mathrm{Zn}^{2+}$ in both overlying water and pore water were measured and simulated with the transport model described above. The effects of the dispersion coefficient $(\alpha)$ and equilibrium constant $\left(K_{a d}\right)$ on the transport of metal ions are then examined.

\section{1 $\mathrm{NaCl}$ and $\mathrm{Zn}^{2+}$ concentrations in the overlying water}

The $\mathrm{NaCl}$ concentration in the overlying water decreased rapidly during the first $5 \mathrm{~h}$ of the experiment (Fig. 3), which can be attributed to the rapid migration of $\mathrm{NaCl}$ from the overlying water to the shallow area of the bedform with a large pore water velocity and associated solute migration flux. However, as the solute front passed through the shallow area, the $\mathrm{NaCl}$ concentration in the overlying water decreased more slowly. Finally, the value of $C / C_{0}$ for $\mathrm{NaCl}$ reached a stable level at around 0.75 . Given that there is no adsorption or reaction of $\mathrm{NaCl}, \mathrm{NaCl}$ would be uniformly 
distributed in the whole system after an infinite time, i.e., $V_{o} /\left(V_{o}+V_{p}\right)=0.75$. A more dramatic decrease is noted for the $\mathrm{Zn}^{2+}$ concentration in the overlying water as it is driven by both advection and adsorption. For $\mathrm{Zn}^{2+}$, the normalized concentration $\left(C / C_{0}\right)$ reaches a stable level lower than 0.40 (Fig. 3), which is much lower than that of $\mathrm{NaCl}$ due to the adsorption of $\mathrm{Zn}^{2+}$ by the streambed.

\subsection{Variation of $\mathrm{Zn}^{2+}$ concentration in the bedform}

The measured and modeled $\mathrm{Zn}^{2+}$ concentrations in the monitoring profiles N1 and N2 (Fig.

1b) at different times are shown in Fig. 4. The modeled results generally compare well with the measurements. Two characteristic coefficients are introduced to describe the intrusion of $\mathrm{NaCl}$ and $\mathrm{Zn}^{2+}$, the maximum-initial concentration ratio $\left(R_{m}=C_{m} / C_{0}\right)$ and intrusion depth $\left(D_{i n}\right)$, where $C_{m}$ is the maximum concentration in a monitoring column at a specific time, and $D_{i n}$ is the depth at which the concentration is $C_{m} / 2$ (Fig. S3).

The simulated $D_{\text {in }}$ of $\mathrm{Zn}^{2+}$ is much shallower compared with measured $D_{\text {in }}$ at 25 min and from 123 - $1825 \mathrm{~min}$ the measured and modeled $D_{\text {in }}$ are almost at same level regardless of errors (Fig. 4a), possibly because of the assumption of equilibrium adsorption of $\mathrm{Zn}^{2+}$ used in the model (Fig. 2a suggests the characteristic time of the adsorption kinetics to be $10-20$ mins). Both the measurements and simulations show that the $\mathrm{Zn}^{2+}$ profiles have lower concentrations near the surface boundary than the maximum concentration measured in the streambed. This occurs due to the continuous reduction of the $\mathrm{Zn}^{2+}$ concentration in the overlying water [52]. The simulations of zinc concentrations in the streambed reflect this change, i.e., the initial high concentration in the stream result in higher concentrations deeper in the streambed, and lower concentrations near the streamstreambed boundary. The same behavior occurs in the $\mathrm{NaCl}$ case, although the reduction in the concentration near the top of the streambed is not obvious. For the concentration distribution in the 
whole bedform, the intrusion area increases and the maximum concentration decreases (Fig. S4)

over time. For the linear adsorption isotherm, the distributions of $C / C_{0}$ and $S / S_{0}$ are the same (Fig. S5).

The $R_{m}$ values show a rapidly increasing trend at the beginning of experiment and then slowly decrease, while the magnitude of $D_{i n}$ increases with time for both $\mathrm{NaCl}$ and $\mathrm{Zn}^{2+}$ (Fig. 5). When comparing the differences between $\mathrm{NaCl}$ and $\mathrm{Zn}^{2+}$, the $R_{m}$ values for $\mathrm{NaCl}$ are larger than those of $\mathrm{Zn}^{2+}$. As well, the corresponding $D_{i n}$ values are also greater, as expected, due to adsorption of $\mathrm{Zn}^{2+}$ (Figs. 4, 5). When comparing the differences between profiles N1 and N2, the curves for both $D_{\text {in }}$ and $R_{m}$ are obviously delayed (Fig. 5). A sharp decreasing trend is observed at the end of the $\mathrm{NaCl}$ curves in Fig. 5b, because the solute has reached the bottom of the profile but the intrusion depth $\left(D_{i n}\right)$ has not reached the bottom (Figs. S3c).

\subsection{Variation of $\mathrm{Zn}^{2+}$ mass in three phases}

Fig. 6 illustrates the trends of $\mathrm{Zn}^{2+}$ mass in three phases: overlying water, pore water and adsorbed to the streambed. Fig. 6a shows the modeled predictions for each phase, as well as $\mathrm{Zn}^{2+}$ in the overlying water from measurements (assumed to be well mixed [42]). The mass of $\mathrm{Zn}^{2+}$ ions decreases in the overlying water but increases in pore water as the adsorption is assumed to be instantaneous (Fig. 6a). The mass of $\mathrm{Zn}^{2+}$ in the overlying water decreases rapidly in the first few hours of the experiment, then reduces more slowly. Correspondingly, the mass of $\mathrm{Zn}^{2+}$ in the pore water and adsorbed phase show opposite trends. Because of instantaneous sorption, the adsorbed mass of $\mathrm{Zn}^{2+}$ is 6.26 times of the mass in pore water (Fig. 6b), as computed from: 


$$
P_{S C}=\frac{\text { mass adsorbed to soil }}{\text { mass in pore water }}=\frac{\int_{m} S d m}{\int_{V_{p}} C d V_{p}}=\frac{\rho_{b} K_{a d}}{\theta}
$$

where $m(\mathrm{~kg})$ is the mass of sand. As the equilibrium constant $\left(K_{a d}\right)$ is fixed for constant $\mathrm{pH}(\mathrm{Eq}$.

13), $P_{S C}$ is also constant. As seen above (Eqs. 3, 4), the partitioning of $\mathrm{Zn}$ depends on $K_{a d}$ and hence

$\mathrm{pH}$. For fixed $\mathrm{pH}$, the adsorbed mass of $\mathrm{Zn}$ increases with $K_{a d}$ and the total mass in overlying water and pore water become smaller (Fig. 6c). Correspondingly, as $K_{a d}$ reduces, so does the total adsorbed mass so that in the limit of no sorption $\left(K_{a d}=0\right)$, we recover the case of $\mathrm{NaCl}$ (Fig. $\left.6 \mathrm{c}\right)$.

The mass ratio of the overlying water phase to pore water phase $\left(P_{O C}\right)$ is defined as:

$$
P_{O C}=\frac{\text { mass in overlying water }}{\text { mass in pore water }}=\frac{\int_{V_{o}} C_{t} d V_{o}}{\int_{V_{p}} C d V_{p}}
$$

Similarly, we define the mass ratio of the adsorbed mass to the mass in the overlying water phase $\left(P_{S O}\right)$ is defined as:

$$
P_{S O}=\frac{\text { mass adsorbed to soil }}{\text { mass in overlying water }}=\frac{\int_{m} S d m}{\int_{V_{o}} C_{t} d V_{o}}
$$

i.e., $P_{S C}=P_{S O} P_{O C}$.

Even though $P_{S C}$ is constant for all $t$, both $P_{S O}$ and $P_{O C}$ vary with $t$ (Fig. 6b). Assuming that no zinc is lost from the experiment, in the long-time limit it will be distributed with uniform concentrations in each of the water and soil phases, i.e., the concentrations in the overlying and pore water will be identical, and the adsorbed concentrations will be uniform throughout the streambed. To generalize the results slightly, we assume that the volume of overlying water is $M$ times that of the pore water (in our experiment, $M=3$ ). Then, it is straightforward to show that, for large $t$ : 


$$
\begin{gathered}
P_{S O}=\frac{\rho_{b} K_{a d}}{M \theta} \\
P_{O C}=M
\end{gathered}
$$

Under the given assumptions, the time scale beyond which Eqs. 17 and 18 hold is defined by the time needed for zinc to spread throughout the porous medium, i.e., it is defined by the flow conditions, and not the reaction kinetics of zinc adsorption.

\subsection{The effects of dispersivities $(\alpha)$}

Fig. 7 (and Fig. S6) illustrates the effects of dispersivities $(\alpha)$ on the concentration in the overlying water, and the $\mathrm{Zn}$ distribution in the bedform. Thus, the variation of $\alpha$ does not affect the concentration in the overlying water (Fig. 7a) as well as the exchange rate between the stream and streambed. However, in terms of the concentration distribution in the bedform, a larger $\alpha$ results in a wider concentration transition zone (Figs. 7b, S6). In spite of this, the concentration distribution above the transition zone is almost the same for different values of $\alpha$ (Fig. 7b). The maximum-initial concentration ratio $\left(R_{m}=C_{m} / C_{0}\right)$ is also affected by $\alpha$ (Fig. 7c). The smaller $\alpha$ is, the larger $R_{m}$ would be, i.e., the diffusive flux is less and the maximum concentrations are increased. The variation of $\alpha$ hardly affects the intrusion depth $\left(D_{i n}\right)$, i.e., $D_{i n}$ is controlled by advection rather than dispersion (Fig. 7c).

\subsection{Effects of equilibrium constants $\left(K_{a d}\right)$}

Here, we consider the effects of different $K_{a d}$ values (i.e., for different $\mathrm{pH}$ values, held constant in a given experiment). For this, two characteristic parameters are defined: the final stable concentration $\left(C_{f}\right)$ and the time to reach half of this concentration $\left(T_{h}\right)$. Note that $C_{f}=C\left(x_{1}, x_{2}, t \rightarrow\right.$ $\infty)$. Using the same assumptions as in Section 4.3, we find that: 
where $m_{Z n \text {,total }}$ is the total mass of zinc in the system (adsorbed and in the water phase). For fixed $m_{Z n, \text { total }}$, it is clear from Eq. 19 that $C_{f}$ decreases as $K_{a d}$ increases, as can be seen in Fig. 8 (and Fig. S6). However, the range of $T_{h} / T_{h 0}(0.7$ to 1.1$)$ is relatively small compared with the range of $K_{a d} / K_{a d 0}$ (ranging from 0 to 4.0). When $K_{a d} / K_{a d 0}$ increases from 0 to 0.5 , the $T_{h} / T_{h 0}$ increases from 0.7 to 1.1 , i.e., the time scale to reach a stable concentration is noticeable. On the contrary, when $K_{a d} / K_{a d 0}$ increases from 0.5 to 4 , the $T_{h} / T_{h 0}$ gradually drops from 1.1 to 0.8 . These results show that the time to reach steady state is, as already noted above, is mainly due to the flow conditions than to the value of the equilibrium constant, $K_{a d}$.

The intrusion depth $\left(D_{i n}\right)$ and the maximum-initial concentration ratio $\left(R_{m}=C_{m} / C_{0}\right)$ decrease with $K_{a d}$ (Fig. 9), because more $\mathrm{Zn}^{2+}$ ions would be adsorbed and thus less $\mathrm{Zn}^{2+}$ ions would be retained in pore water. Figure 9 shows that $R_{m}$ at profiles N1 and N2 is nearly identical, i.e., insensitive to $K_{a d}$. However, the range of $D_{i n}$ is greater for profile N2 compared to N1, i.e., $D_{i n}$ varies in a wider range on the lee-side of bedform as $K_{a d}$ varies.

The intrusion depth $\left(D_{i n}\right)$ becomes deeper and the maximum-initial concentration ratio $\left(R_{m}\right)$ becomes smaller over time (Fig. S9) even for $\mathrm{NaCl}$ (Fig. S3c). Fig. S9 shows that adsorption can significantly reduce the intrusion depth $\left(D_{i n}\right)$ and the maximum-initial concentration ratio $\left(R_{m}\right)$. And the maximum-initial concentration ratio $\left(R_{m}\right)$ reduces also with larger $K_{a d}$ (Fig. S9), indicating that the concentration of contaminants in the overlying water also decreases over time (Fig. S7). Thus, the decrease in the maximum-initial concentration ratio $\left(R_{m}\right)$ of $\mathrm{Zn}^{2+}$ over time (Fig. S9) can be attributed to the decreasing concentration in the overlying water and adsorption in the bedform. A comparison of Fig. S4a and $\mathrm{b}$ shows that the intrusion depth $\left(D_{\text {in }}\right)$ is deeper on the stoss side of the 
bedform, but the maximum-initial concentration ratio $\left(R_{m}\right)$ remains almost unchanged on both sides,

indicating that the intrusion time on the lee side is postponed.

The maximum-initial concentration ratio $\left(R_{m}\right)$ increases sharply and then decreases slowly to a stable level; whereas the intrusion depth $\left(D_{i n}\right)$ increases continuously (Fig. S10). Comparisons of Fig. S10a $\&$ b and Fig. 9c $\& d$ show that the time is postponed in Fig. S10b \& d because ions are first migrated to the stoss side (N1) and then slowly carried out from the lee side (N2). A sharp decreasing trend is observed at the end of case $K_{a d}=0.25 K_{a d 0}$ in Fig. S10c, because the front tip of the concentration intrusion curve has reached the bottom of the profile ahead of the intrusion depth $\left(D_{\text {in }}\right)$ (Fig. S3). As the intrusion depth $\left(D_{i n}\right)$ reaches the bottom of the bedform, it is maintained at $12 \mathrm{~cm}$ (Fig. S10c, Fig. S3c), as is apparent for $\mathrm{NaCl}$ in Fig. S10c.

A new coefficient, the half depth arrival time $\left(T_{a}\right)$ at which the intrusion depth $D_{i n}=-6 \mathrm{~cm}$ (Fig. S10), is defined to represent the time for the intrusion line to reach a certain depth. Fig. 10 shows that there is a linear correlation between the half depth arrival time $\left(T_{a}\right)$ and the equilibrium constant for linear adsorption $\left(K_{a d}\right)$, and thus the larger the value of $K_{a d}$, the longer the arrival time will be. However, it is noted that the arrival times are delayed on the lee side of the bedform.

All these results suggest that adsorption prevents the intrusion of ions into the streambed, which can reduce the pollution of groundwater but can also cause higher accumulation of contaminated metals in the hyporheic zone, and as a consequence secondary pollution may occur if these metal ions are released back to the overlying water.

\section{Conclusions}

In this study, experiments and numerical simulations were performed to investigate the 
adsorption of $\mathrm{Zn}^{2+}$ ions and their transport in the hyporheic zone. The main conclusions are:

1) Adsorption leads to a more rapid decrease of $\mathrm{Zn}^{2+}$ concentration in the overlying water compared with non-adsorbing case $(\mathrm{NaCl})$. The variation of $\mathrm{Zn}^{2+}$ concentration in the overlying water is sensitive to the equilibrium constant. The larger the adsorption coefficient is, the more rapidly the concentration decreases.

2) The mass in three phases varies rapidly at beginning (increasing in pore water and adsorbed phase, decreasing in overlying water) and finally reaches an equilibrium. The sum of $\mathrm{Zn}^{2+}$ in pore water and adsorbed phase is strictly equal to the decreasing mass in overlying water. The adsorbed mass of metal ions is more than 6 times higher than the pore water phased mass.

3) The strong function of adsorption prevents the intrusion of ions into the streambed and thus mitigates the pollution of groundwater, but will also cause higher accumulation of contaminated metals in the shallower layer of hyporheic zone.

Knowledge of the transport of metal ions in the hyporheic zone may provide important insights into the restoration of polluted rivers. Next important research direction is to elucidate the interactions of metal ions and particles in the hyporheic zone. Fine sediments and colloidal particles can act as a carrier of metal ions $[34,43]$, which may lead to higher accumulations of contaminants in the hyporheic zone. 


\section{Acknowledgments}

This research has been supported by the Natural Science Foundation of China (51679065), the

\section{Basic Research Programs (Natural Science Foundation) of Jiangsu Province (BK20171436), Social}

\section{Development - Major Demonstration of Science and Technology of Science and Technology}

Projects of Jiangsu Province (BE2018737); and the 111 Project (B17015), Ministry of Education and State Administration of Foreign Experts Affairs, P. R. China.

\section{References}

1 Järup, L. (2003). Hazards of heavy metal contamination. British medical bulletin, 68(1), 167-182. https://doi.org/10.1093/bmb/ldg032

2 Islam, M. S., Ahmed, M. K., Raknuzzaman, M., Habibullah-Al-Mamun, M., \& Islam, M. K. (2015). Heavy metal pollution in surface water and sediment: A preliminary assessment of an urban river in a developing country. Ecological Indicators, 48, 282-291.https://doi.org/10.1016/j.ecolind.2014.08.016

3 Varol, M. (2011). Assessment of heavy metal contamination in sediments of the Tigris River (Turkey) using pollution indices and multivariate statistical techniques. Journal of Hazardous Materials, 195, 355364.https://doi.org/10.1016/j.jhazmat.2011.08.051

4 Liu, G., Tao, L., Liu, X., Hou, J., Wang, A., \& Li, R. (2013). Heavy metal speciation and pollution of agricultural soils along Jishui River in non-ferrous metal mine area in Jiangxi Province, China. Journal of Geochemical Exploration, 132, 156-163.https://doi.org/10.1016/j.gexplo.2013.06.017

5 Milenkovic, N., Damjanovic, M., \& Ristic, M. (2005). Study of Heavy Metal Pollution in Sediments from the Iron Gate (Danube River), Serbia and Montenegro. Polish Journal of Environmental Studies, 14(6).

6 Jabłońska-Czapla, M., Nocoń, K., Szopa, S., \& Łyko, A. (2016). Impact of the $\mathrm{Pb}$ and $\mathrm{Zn}$ ore mining industry on the pollution of the Biała Przemsza River, Poland. Environmental monitoring and assessment, 188(5), 262.https://doi.org/10.1007/s10661-016-5233-3

7 Li, X., Wai, O. W., Li, Y. S., Coles, B. J., Ramsey, M. H., \& Thornton, I. (2000). Heavy metal distribution in sediment profiles of the Pearl River estuary, South China. Applied Geochemistry, 15(5), 567581.https://doi.org/10.1016/s0883-2927(99)00072-4

8 Haileslassie, T., \& Gebremedhin, K. (2015). Hazards of heavy metal contamination in ground water. International Journal of Technology Enhancements and Emerging Engineering Research, 3(2), 1-6.

9 Giller, K. E., Witter, E., \& McGrath, S. P. (1998). Toxicity of heavy metals to microorganisms and microbial processes in agricultural soils: A review. Soil biology and biochemistry, 30(10-11), 13891414.https://doi.org/10.1016/s0038-0717(97)00270-8 
10 Ogunleye, P. O., Mayaki, M. C., \& Amapu, I. Y. (2002). Radioactivity and heavy metal composition of Nigerian phosphate rocks: Possible environmental implications. Journal of environmental radioactivity, 62(1), 39-48.https://doi.org/10.1016/s0265-931x(01)00149-7

11 Dalmacija, B., Prica, M., Ivancev-Tumbas, I., Van der Kooij, A., Roncevic, S., Krcmar, D., ... \& Teodorovic, I. (2006). Pollution of the Begej Canal sediment-metals, radioactivity and toxicity assessment. Environment International, 32(5), 606-615.https://doi.org/10.1016/j.envint.2006.01.006

12 Bajracharya, K., Y. T. Tran, and D. A. Barry. 1996. Cadmium adsorption at different pore water velocities. Geoderma. 73(3-4): 197-216. DOI: 10.1016/0016-7061(96)00048-1

13 Gandy, C. J., Smith, J. W. N., \& Jarvis, A. P. (2007). Attenuation of mining-derived pollutants in the hyporheic zone: A review. Science of the Total Environment, 373(2-3), 435-446. https://doi.org/10.1016/j.scitotenv.2006.11.004

14 Borgmann, U., \& Norwood, W. P. (1997). Toxicity and accumulation of zinc and copper in Hyalella azteca exposed to metal-spiked sediments. Canadian Journal of Fisheries and Aquatic Sciences, 54(5), 10461054.https://doi.org/10.1139/f97-020

15 Kookana, R. S., R. Naidu, D. A. Barry, Y. T. Tran, and K. Bajracharya. 1999. Sorption-desorption equilibria and dynamics of cadmium during transport in soil. In Fate and Transport of Heavy Metals in the Vadose Zone. Editors: H. M. Selim and I. K. Iskandar, Lewis Publishers, Boca Raton, Florida, Chapter 3, pp. 59-90.

16 Al Bakheet, S. A., Attafi, I. M., Maayah, Z. H., Abd-Allah, A. R., Asiri, Y. A., \& Korashy, H. M. (2013). Effect of long-term human exposure to environmental heavy metals on the expression of detoxification and DNA repair genes. Environmental Pollution, 181, 226-232.https://doi.org/10.1016/j.envpol.2013.06.014

17 Ou, X., Zhang, Y., Xu, C., Lin, X., Zang, Q., Zhuang, T., ... \& Liu, B. (2012). Transgenerational inheritance of modified DNA methylation patterns and enhanced tolerance induced by heavy metal stress in rice (Oryza sativa L.). PloS One, 7(9), e41143.https://doi.org/10.1371/journal.pone.0041143

18 Dallinger, R., Prosi, F., Segner, H., \& Back, H. (1987). Contaminated food and uptake of heavy metals by fish: A review and a proposal for further research. Oecologia, 73(1), 9198.https://doi.org/10.1007/bf00376982

19 Cheng, Z., Man, Y. B., Nie, X. P., \& Wong, M. H. (2013). Trophic relationships and health risk assessments of trace metals in the aquaculture pond ecosystem of Pearl River Delta, China. Chemosphere, 90(7), 21422148.https://doi.org/10.1016/j.chemosphere.2012.11.017

20 Türkdoğan, M. K., Kilicel, F., Kara, K., Tuncer, I., \& Uygan, I. (2003). Heavy metals in soil, vegetables and fruits in the endemic upper gastrointestinal cancer region of Turkey. Environmental toxicology and pharmacology, 13(3), 175-179.https://doi.org/10.1016/s1382-6689(02)00156-4

21 Triska, F. J., Kennedy, V. C., Avanzino, R. J., Zellweger, G. W., \& Bencala, K. E. (1989). Retention and transport of nutrients in a third - order stream in northwestern California: Hyporheic processes. Ecology, 70(6), 1893-1905. DOI: $10.2307 / 1938120$

22 Triska, F. J., Kennedy, V. C., Avanzino, R. J., Zellweger, G. W., \& Bencala, K. E. (1989). Retention and transport of nutrients in a third - order stream: Channel processes. Ecology, 70(6), 1877-1892. DOI:

$10.2307 / 1938119$ 
23 Findlay S. Importance of surface-subsurface exchange in stream ecosystems: The hyporheic zone. Limnology and Oceanography, 1995, 40(1):159-164. DOI: 10.4319/1o.1995.40.1.0159

24 Boulton, A.J.; Findlay, S.; Marmonier, P.; Stanley, E.H.; Valet, H.M. (1998). The functional significance of the hyporheic zone in streams and rivers. Annual Review of Ecological Systems, 29, 5981.https://doi.org/10.1146/annurev.ecolsys.29.1.59

25 Stubbington R. (2012). The hyporheic zone as an invertebrate refuge: A review of variability in space, time, taxa and behaviour. Marine and Freshwater Research, 63(4): 293-311. DOI: 10.1071/MF11196

26 Battin TJ, Besemer K, Bengtsson MM, et al. The ecology and biogeochemistry of stream biofilms. Nature Reviews Microbiology, 2016, 14(4):251-263. DOI: 10.1038/nrmicro.2016.15

27 Bourg, A.C.M.; Bertine, C. (1993). Biogeochemical processes during the infiltration of river water into an alluvial aquifer. Environmental Science and Technology, 27, 661-666.https://doi.org/10.1021/es00041a009

28 Zhu, H. W., Zhong, B. C., \& Wang, D. Z. (2014). Sediment rarefaction resuspension and contaminant release under tidal currents. Journal of Hydrodynamics, 26(5), 827-834. https://doi.org/10.1016/S10016058(14)60091-3

29 Jin, G., Tang, H., Li, L., \& Barry, D. A. (2015). Prolonged river water pollution due to variable-density flow and solute transport in the riverbed. Water Resources Research, 51(4), 1898-1915. https://doi.org/10.1002/2014WR016369

30 Fuller CC, Harvey JW. Reactive uptake of trace metals in the hyporheic zone of a mining-contaminated stream, Pinal Creek, Arizona. Environ Sci Technol 2000;34:1150 5.https://doi.org/10.1021/es990714d

31 Winde, F., \& van der Walt, I. J. (2004). The significance of groundwater-stream interactions and fluctuating stream chemistry on waterborne uranium contamination of streams - a case study from a gold mining site in South Africa. Journal of Hydrology, 287(1-4), 178-196.ttps://doi.org/10.1016/j.jhydrol.2003.10.004

32 Fuller, C. C., \& Bargar, J. R. (2014). Processes of zinc attenuation by biogenic manganese oxides forming in the hyporheic zone of Pinal Creek, Arizona. Environmental science \& technology, 48(4), 21652172.https://doi.org/10.1021/es402576f

33 Peña, J., Kwon, K. D., Refson, K., Bargar, J. R., \& Sposito, G. (2010). Mechanisms of nickel sorption by a bacteriogenic birnessite. Geochimica et Cosmochimica Acta, 74(11), 30763089.https://doi.org/10.1016/j.gca.2010.02.035

34 Ren, J., \& Packman, A. I. (2004). Stream-subsurface exchange of zinc in the presence of silica and kaolinite colloids. Environmental Science \& Technology, 38(24), 6571-6581.https://doi.org/10.1021/es035090x

35 Ren, J., \& Packman, A. I. (2005). Coupled stream-subsurface exchange of colloidal hematite and dissolved zinc, copper, and phosphate. Environmental Science \& Technology, 39(17), 6387-

6394.https://doi.org/10.1021/es050168q

36 Palumbo-Roe, B., Wragg, J., \& Banks, V. J. (2012). Lead mobilisation in the hyporheic zone and river bank sediments of a contaminated stream: Contribution to diffuse pollution. Journal of Soils and Sediments, 12(10), 1633-1640. https://doi.org/10.1007/s11368-012-0552-7

37 Palumbo-Roe, B., Banks, V. J., Bonsor, H. C., Hamilton, E. M., \& Watts, M. J. (2017). Limitations on the 
role of the hyporheic zone in chromium natural attenuation in a contaminated urban stream. Applied Geochemistry, 83, 108-120.https://doi.org/10.1016/j.apgeochem.2017.02.011

38 Yu, K., Duan, Y., Liao, P., Xie, L., Li, Q., Ning, Z., \& Liu, C. (2019). Watershed-scale distributions of heavy metals in the hyporheic zones of a heavily polluted Maozhou River watershed, southern China. Chemosphere, 124773.https://doi.org/10.1016/j.chemosphere.2019.124773

39 Ward, A.S. (2016). The evolution and state of interdisciplinary hyporheic research. Wiley Interdisciplinary Reviews Water, 3, 83-103.https://doi.org/10.1002/wat2.1120

40 Packman, A. I., Brooks, N. H., \& Morgan, J. J. (2000). Kaolinite exchange between a stream and streambed: Laboratory experiments and validation of a colloid transport model. Water Resources Research, 36(8), 23632372.https://doi.org/10.1029/2000wr900058

41 Cardenas, M. B., \& Wilson, J. L. (2006). The influence of ambient groundwater discharge on exchange zones induced by current-bedform interactions. Journal of Hydrology, 331(1-2), 103109.https://doi.org/10.1016/j.jhydrol.2006.05.012

42 Jin, G., Tang, H., Li, L., \& Barry, D. A. (2011). Hyporheic flow under periodic bed forms influenced by lowdensity gradients. Geophysical Research Letters, 38(22). https://doi.org/10.1029/2011GL049694

43 Jin, G., Zhang, Z., Tang, H., Xiaoquan, Y., Li, L., \& Barry, D. A. (2019). Colloid transport and distribution in the hyporheic zone. Hydrological Processes, 33(6), 932-944.https://doi.org/10.1002/hyp.13375

44 Jin, G., Tang, H., Gibbes, B., Li, L., \& Barry, D. A. (2010). Transport of nonsorbing solutes in a streambed with periodic bedforms. Advances in Water Resources, 33(11), 1402-1416. https://doi.org/10.1016/j.advwatres.2010.09.003

45 Barry, D. A., C. T. Miller, and P. J. Culligan-Hensley. 1996. Temporal discretisation errors in non-iterative split-operator approaches to solving chemical reaction/groundwater transport models. Journal of Contaminant Hydrology. 22(1-2): 1-17. DOI: 10.1016/0169-7722(95)00062-3.

46 Barry, D. A., K. Bajracharya, and C. T. Miller. 1996. Alternative split-operator approach for solving chemical reaction/groundwater transport models. Advances in Water Resources. 19(5): 261-275. DOI: 10.1016/0309-1708(96)00002-4.

47 Barry, D. A., C. T. Miller, P. J. Culligan, and K. Bajracharya. 1997. Analysis of split operator methods for nonlinear and multispecies groundwater chemical transport models. Mathematics and Computers in Simulation. 43(3-6): 331-341. DOI: 10.1016/S0378-4754(97)00017-7.

48 Barry, D. A. 1992. Modelling contaminant transport in the subsurface: Theory and computer programs. In Modelling Chemical Transport in Soil: Natural and Applied Contaminants, H. Ghadiri and C. W. Rose (editors), Lewis Publishers, Boca Raton, Florida, pp. 105-144.

49 Barry, D. A., and G. Sposito. 1988. Application of the convection-dispersion model to solute transport in finite soil columns. Soil Science Society of America Journal. 52(1): 3-9. DOI: 10.2136/sssaj1988.03615995005200010001x.

50 Parlange, J.-Y., J. L. Starr, M. Th. van Genuchten, D. A. Barry, and J. C. Parker. 1992. Exit condition for miscible displacement experiments in finite columns. Soil Science. 153(3): 165-171. DOI: 10.1097/00010694-199203000-00001. 
51 Dzombak, D.A., and Morel, F.M.M., 1990, Surface complexation modeling-Hydrous ferric oxide: New York, John Wiley, 393 p.

52 Jin, G., Yang, W., Xu, H., Zhang, Z., Yuan, S., Tang, H., Li, L. \& Barry, D. A. (2020). Density effects on solute release from streambeds. Hydrological Processes, 34(5), 1144-1153. https://doi.org/10.1002/hyp.13655 


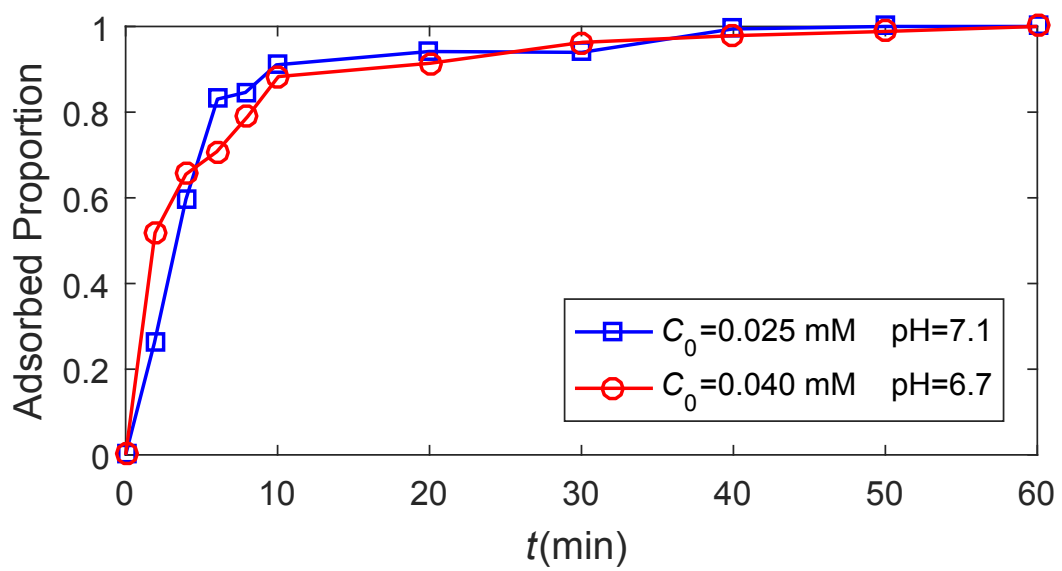

(a)

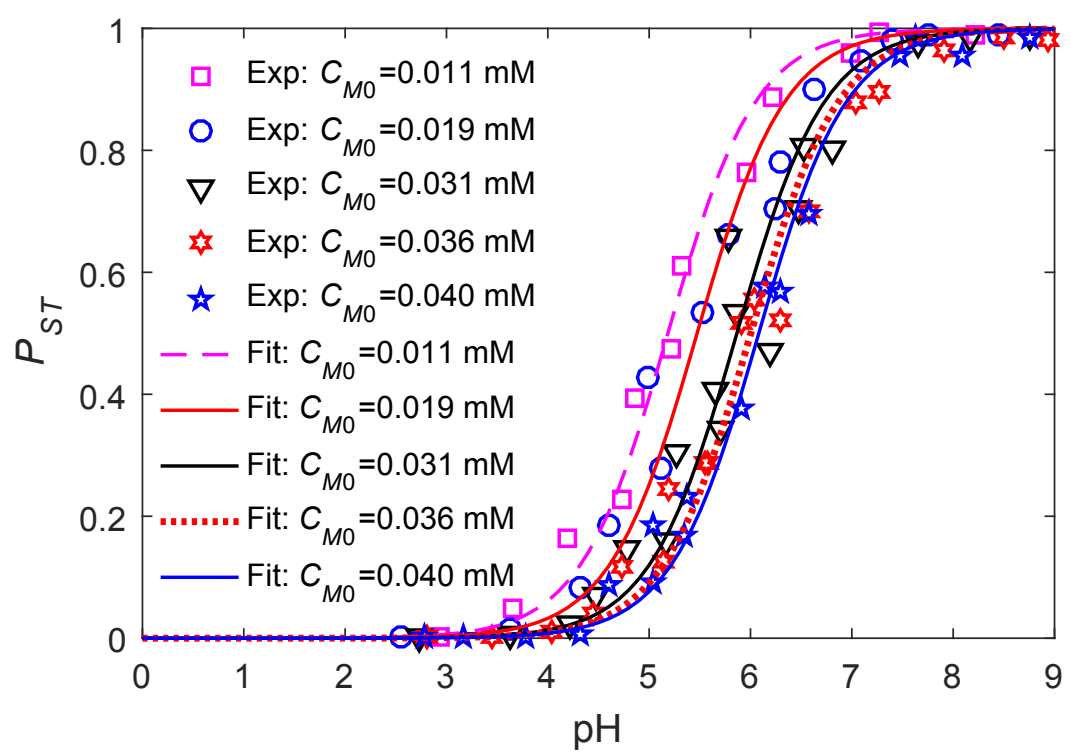

(b)

Fig. 2. (a) The adsorption kinetics between sediment and $\mathrm{Zn}^{2+}$. (b) Data and fitted curves (at steady state) from batch adsorption experiments. 


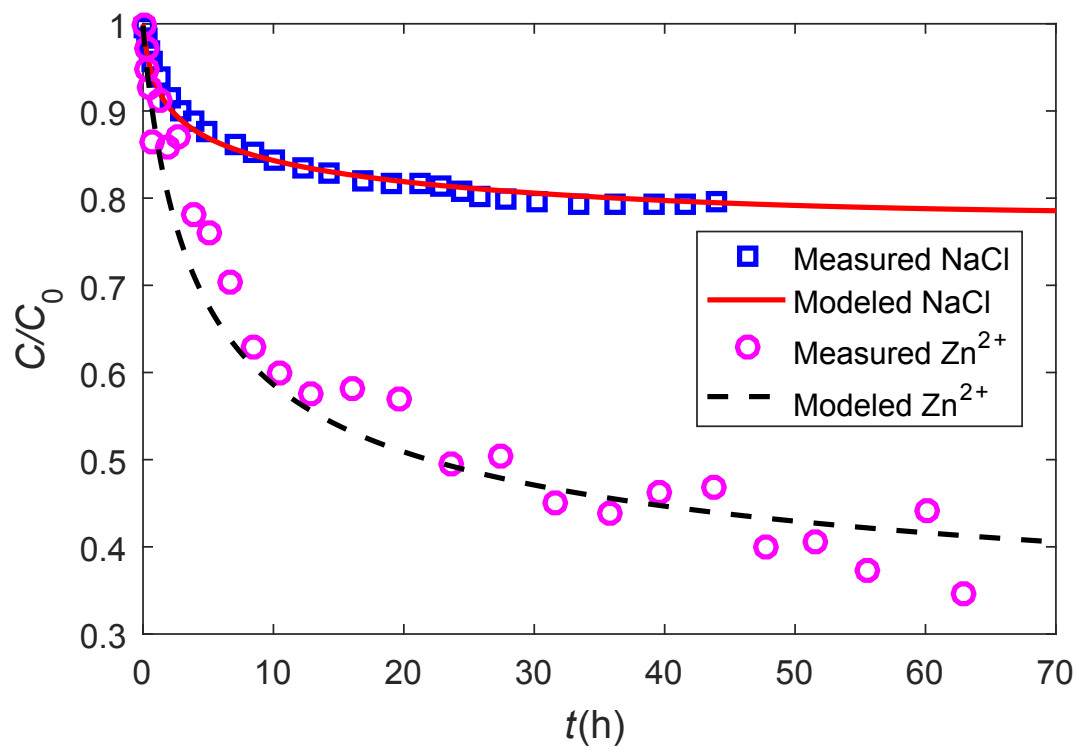

Fig. 3. Variation of $\mathrm{Zn}^{2+}$ and $\mathrm{NaCl}$ concentrations in the overlying water. 


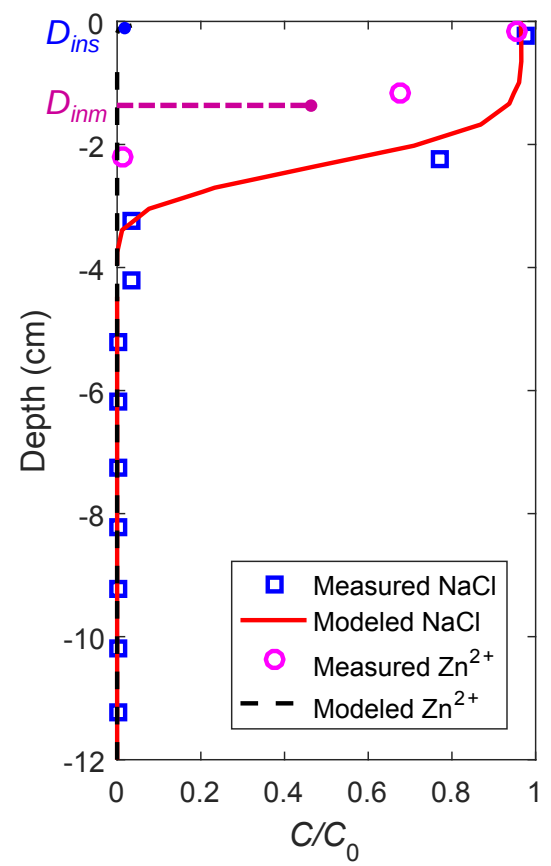

$25 \mathrm{~min}$

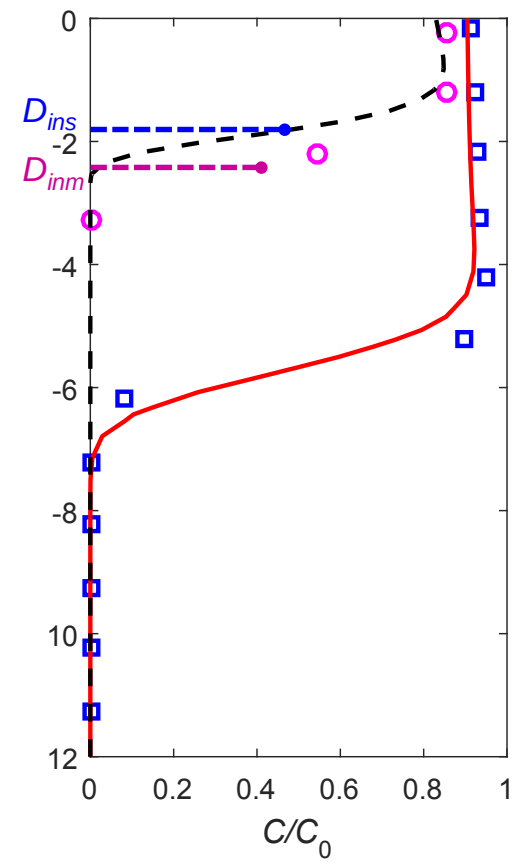

$123 \mathrm{~min}$

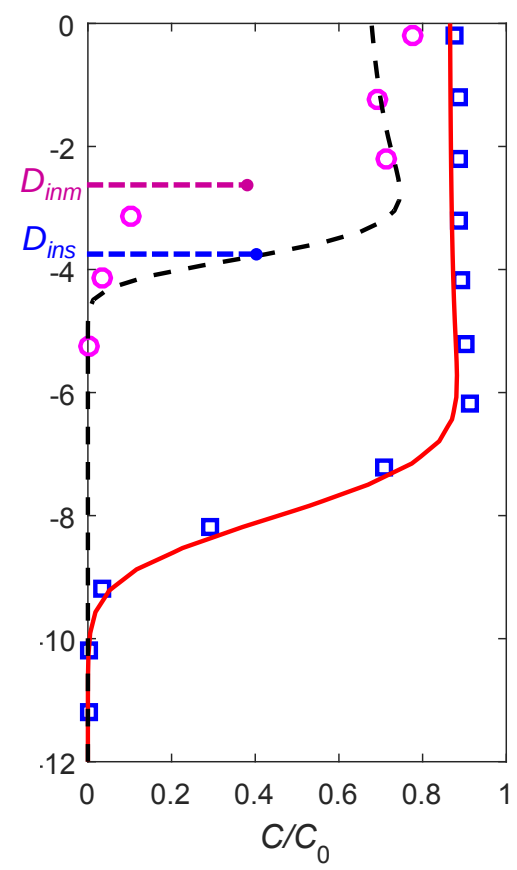

$333 \mathrm{~min}$

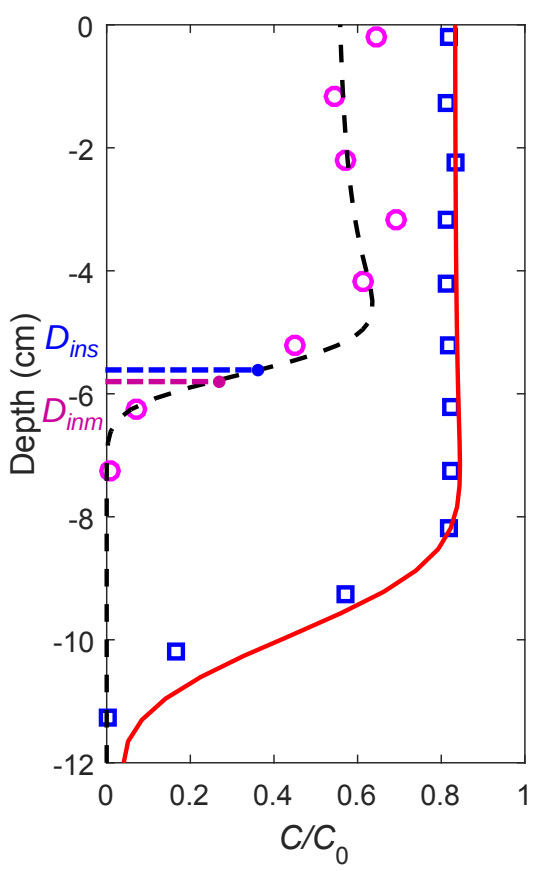

$797 \mathrm{~min}$

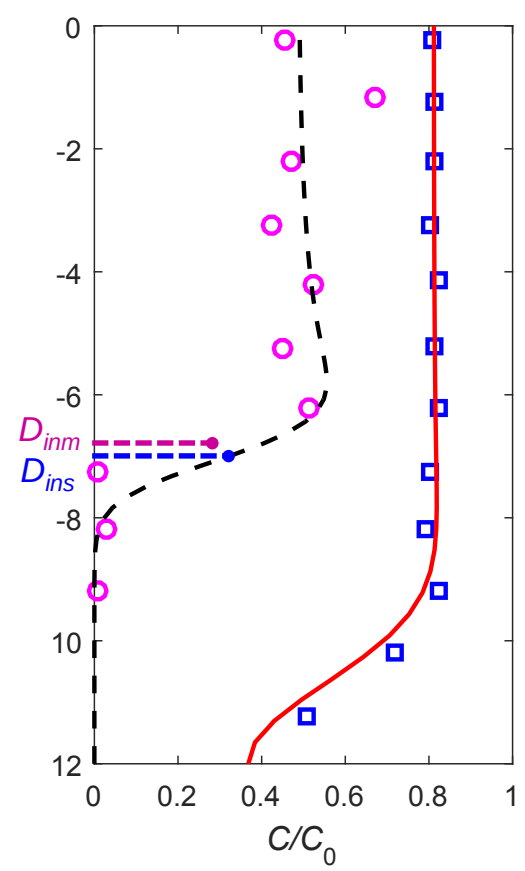

$1491 \mathrm{~min}$

(a)

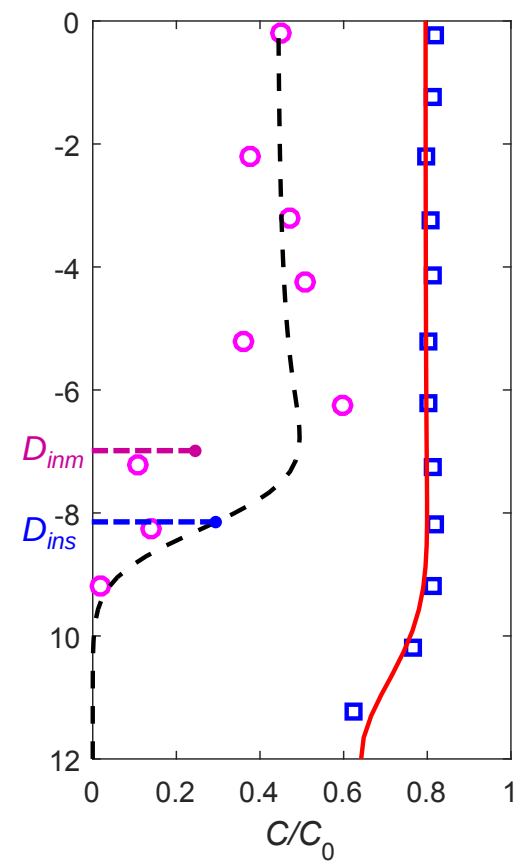

$1528 \mathrm{~min}$ 


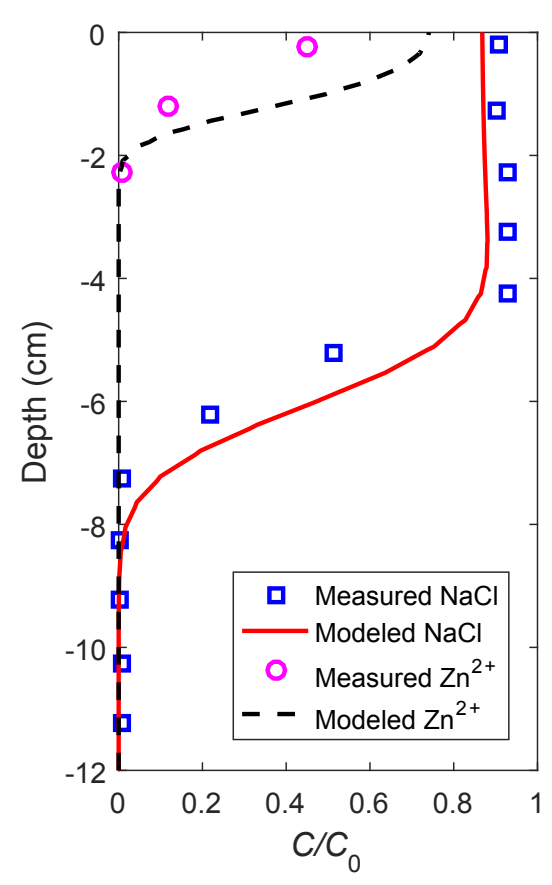

$343 \mathrm{~min}$

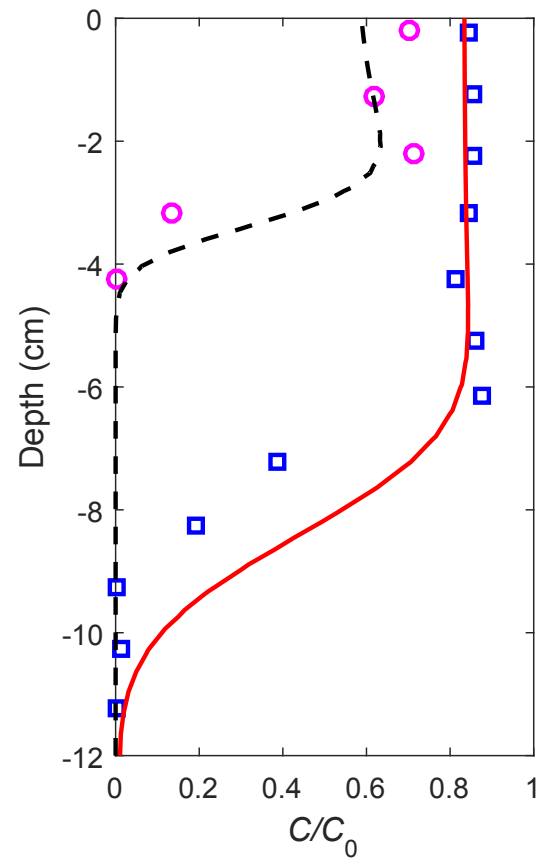

806 min

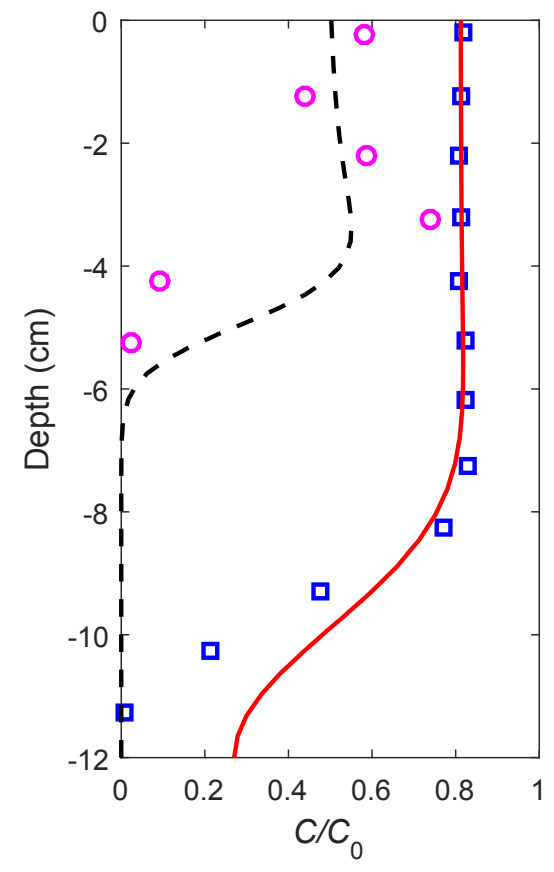

1507 min

(b)

Fig. 4. Variation of $\mathrm{Zn}^{2+}$ concentration in the pore water in monitoring column N1 (a) and N2 (b) at different times. The intrusion depths of $\mathrm{Zn}^{2+}$ from simulation $\left(D_{\text {ins }}\right)$ and from measurement $\left(D_{\text {inm }}\right)$ are labeled by blue and magenta dash line, respectively. 


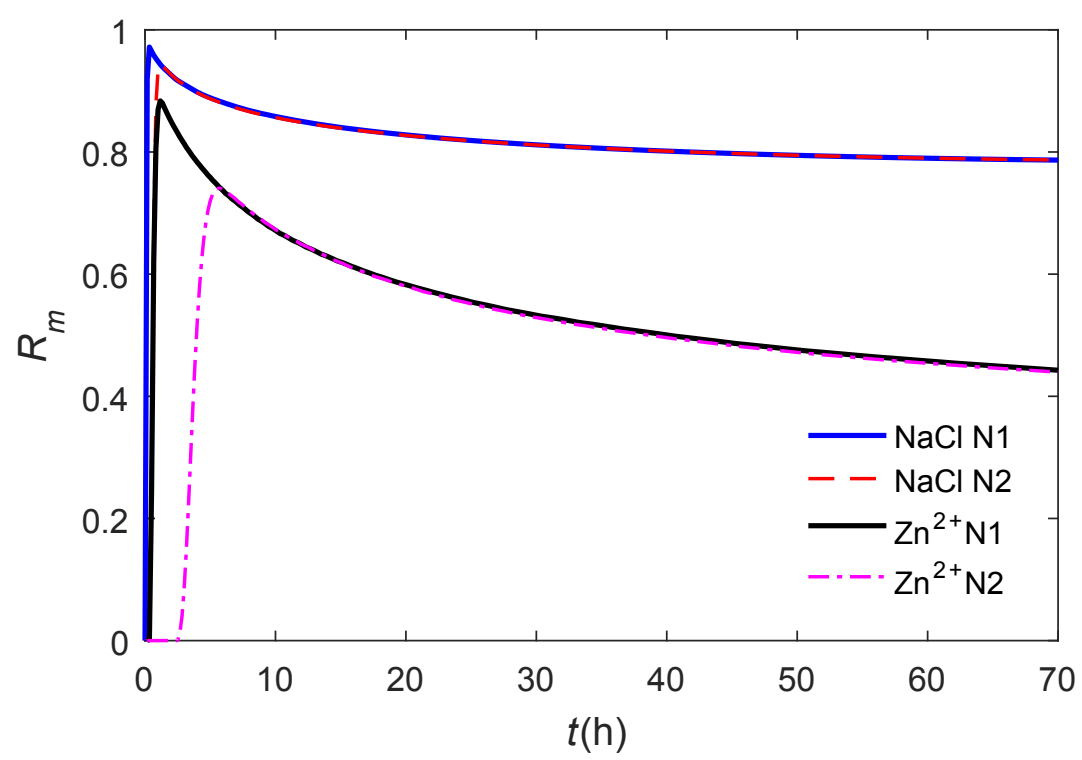

(a)

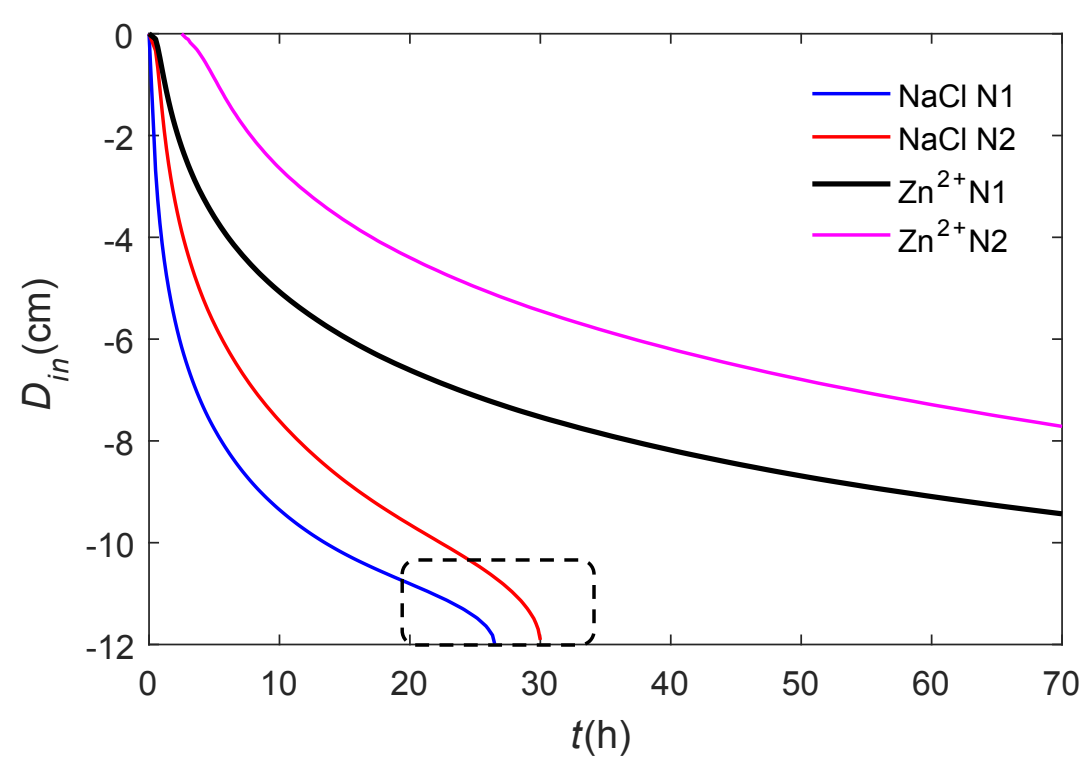

(b)

Fig. 5. The maximum-initial concentration ratio $R_{m}$ (a) and intrusion depth $D_{i n}$ (b) variations for $\mathrm{NaCl}$ and $\mathrm{Zn}^{2+}$ at profiles N1 and N2. A sharp decreasing trend is observed (in the dash box) at the end of case $\mathrm{NaCl}$ 31 for $D_{i n}$ because the front tip of the concentration intrusion curve has reached the bottom of the profile ahead of the intrusion depth (Fig. S6). 


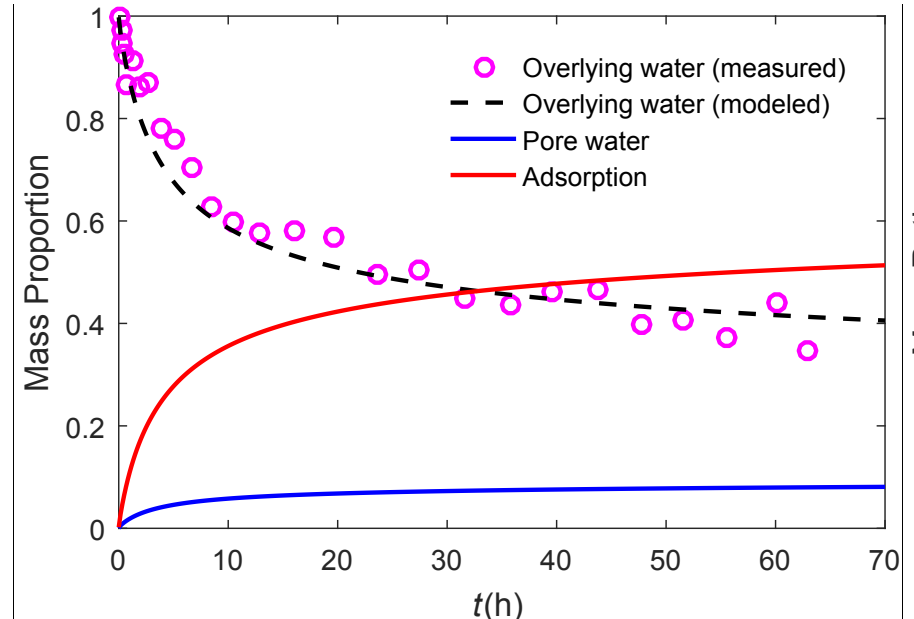

(a)

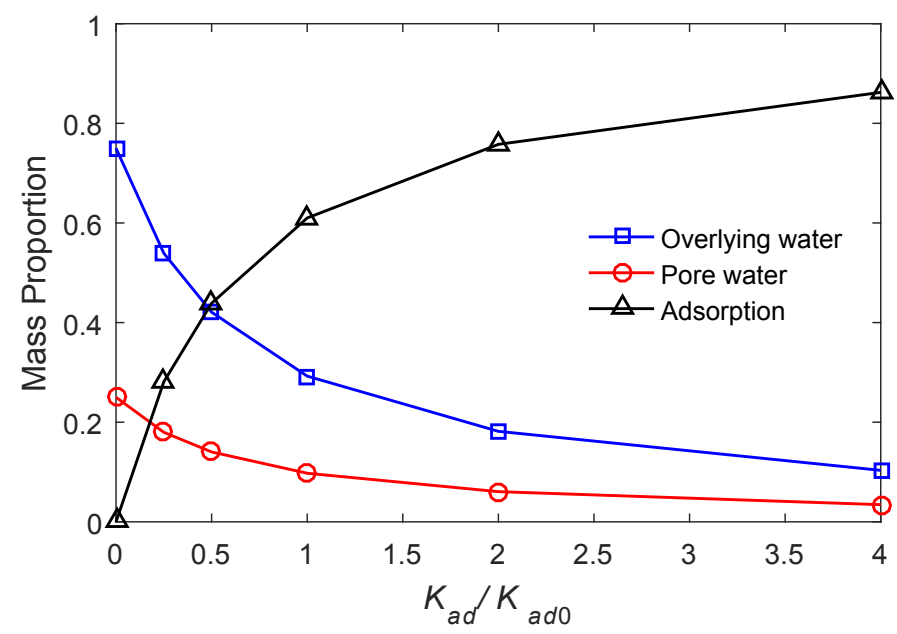

(c)

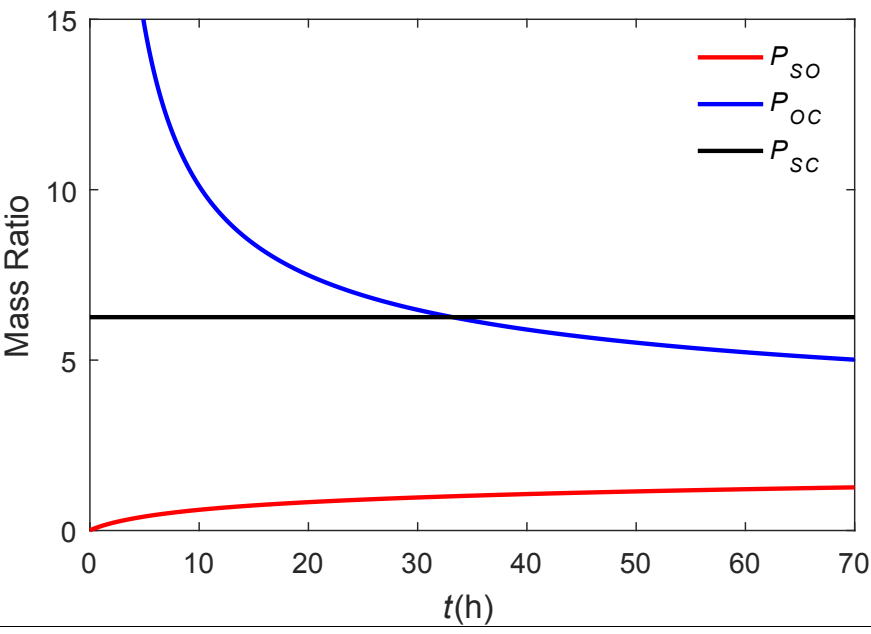

(b)

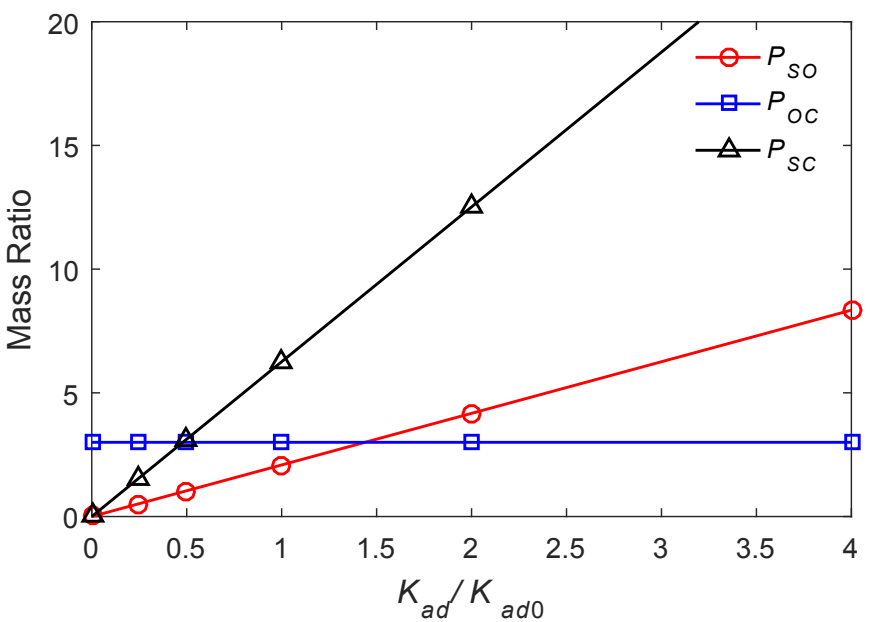

(d)

Fig. 6. (a) Variations of mass proportions of $\mathrm{Zn}^{2+}$ in three phases with time $\left(K_{a d}=K_{a d 0}\right)$. (b) Mass ratio of adsorption to overlying water phase $\left(P_{S O}\right)$, overlying water phase to pore water phase $\left(P_{O C}\right)$, and adsorption to pore water phase $\left(P_{S C}\right)$. (c) Final stable mass proportions with different $K_{a d}$ values. The value of $K_{a d 0}$ is from Table 1. (d) Final mass ratio of adsorption to overlying water phase $\left(P_{S O}\right)$, overlying water phase to pore water phase $\left(P_{O C}\right)$, and and adsorption to pore water phase $\left(P_{S C}\right)$. 


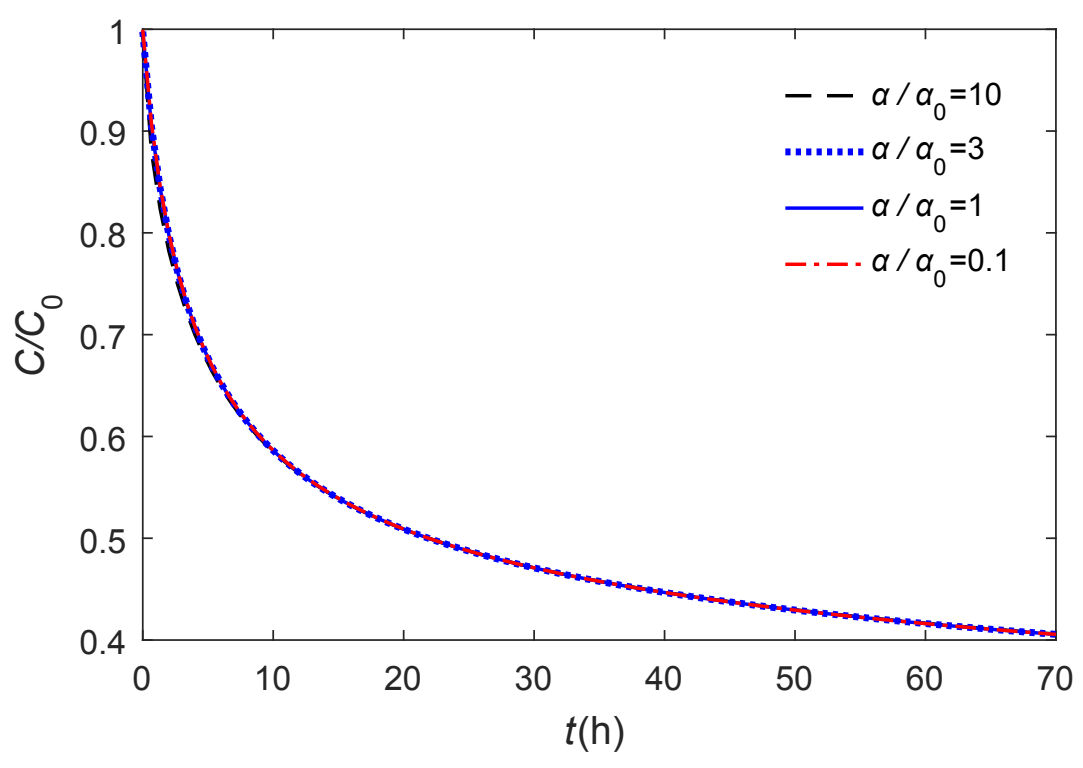
44

(a)

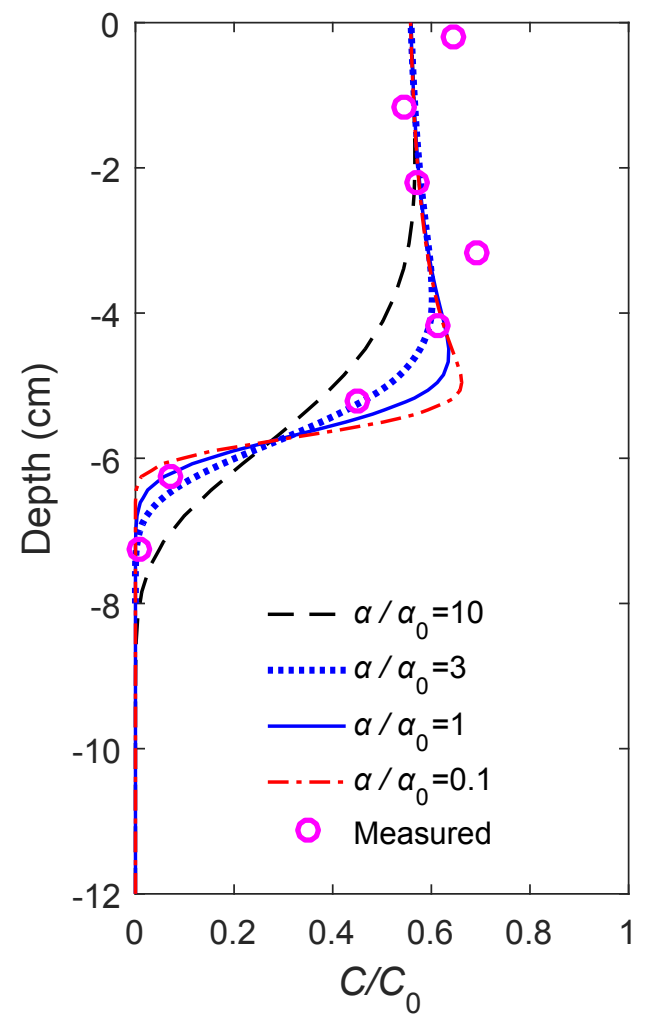

(b)

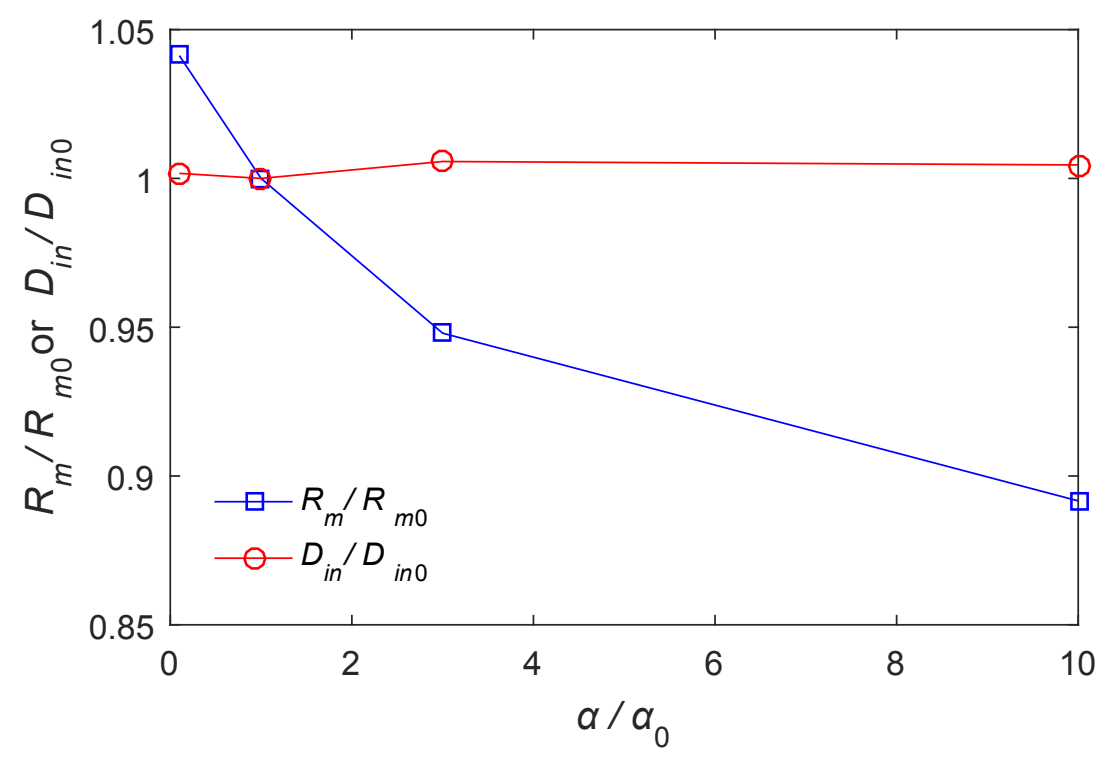

(c)

Fig. 7. Effects of dispersivities $(\alpha)$. (a) Concentration in overlying water for different $\alpha$. (b) $\mathrm{Zn}^{2+}$ concentration in the pore water at $t=797 \mathrm{~min}$ in profile N1. (c) Variation of $R_{m} / R_{m 0}$ and $D_{i n} / D_{i n 0}$. 


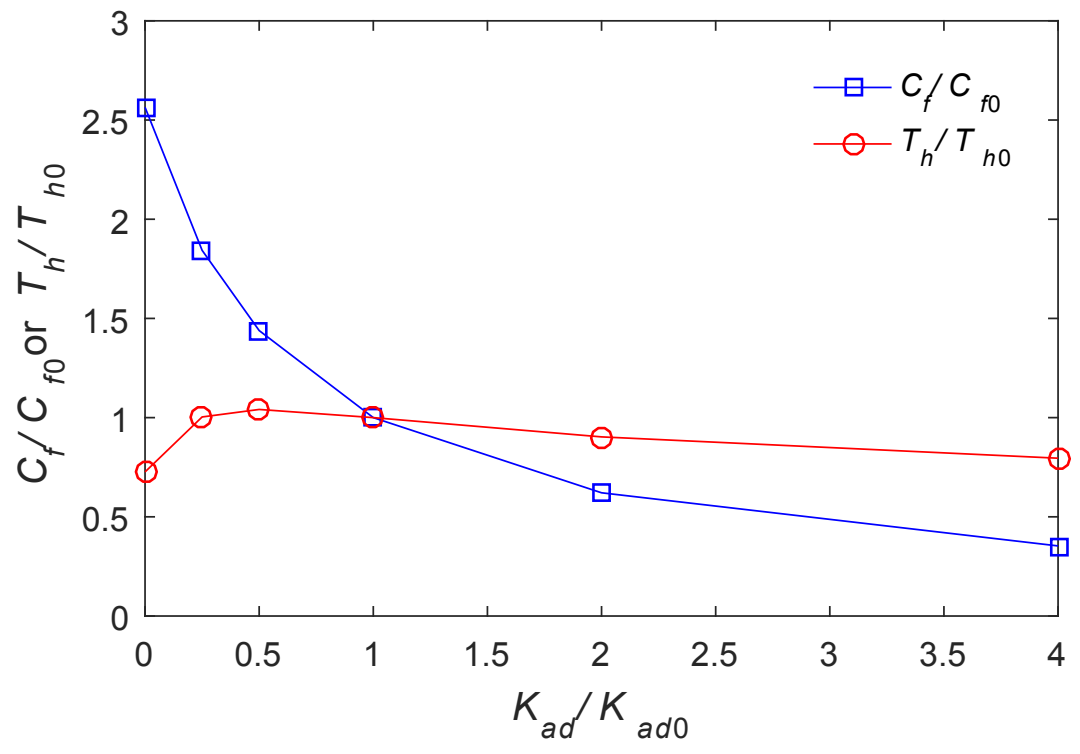

Fig. 8. Variation of the final stable concentration $\left(C_{f}\right)$ and half concentration arrival time $\left(T_{h}\right)$ with the 51 equilibrium constant $\left(K_{a d}\right)$. 


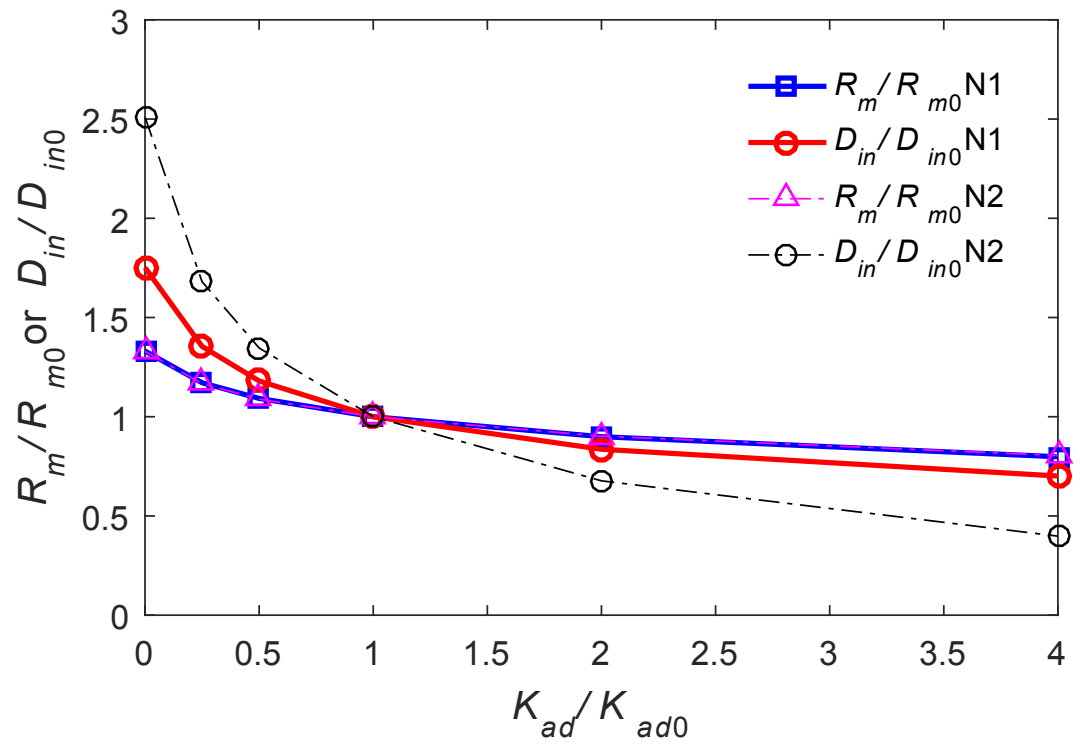

Fig. 9. Variation of the maximum-initial concentration ratio $\left(R_{m}\right)$ and intrusion depth $\left(D_{i n}\right)$ with the equilibrium constant $\left(K_{a d}\right)$ at $797 \mathrm{~min}$. 


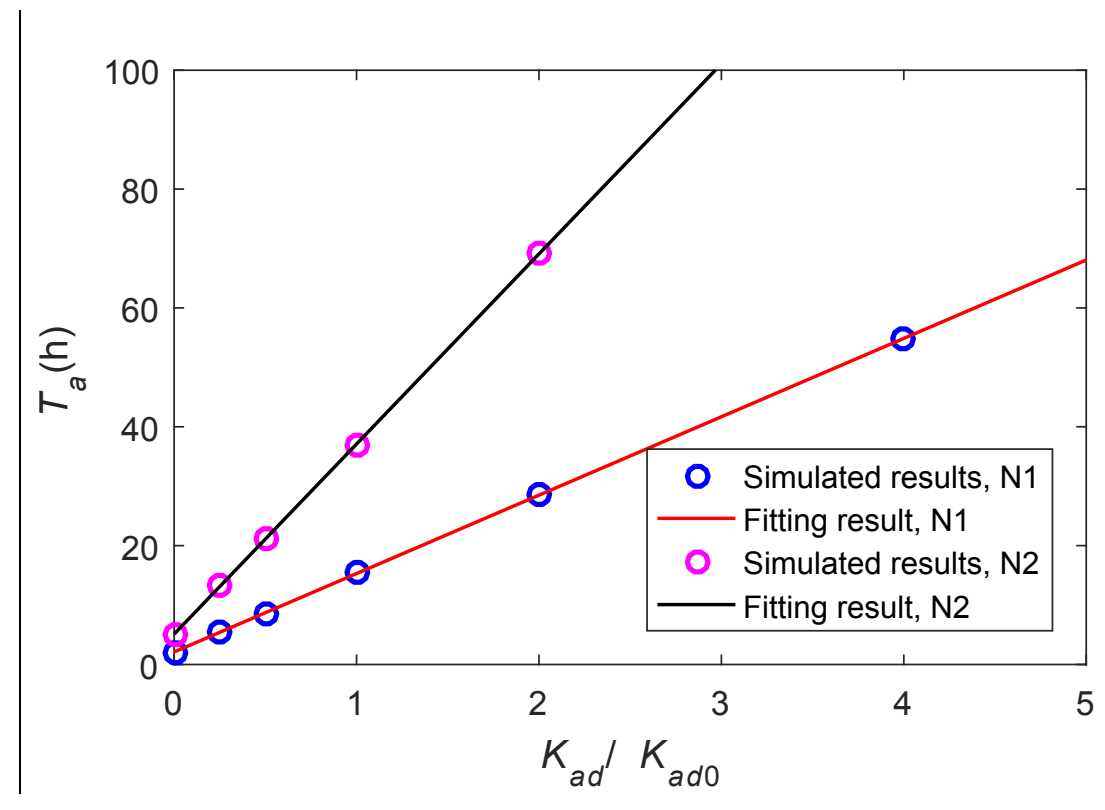

Fig. 10. Relationship between the arrival time at column N1 and $K_{a d} / K_{a d 0}$. The circles represent the 57 simulation results and the lines are linear fits. $K_{a d 0}$ is the fitted equilibrium constant based on measured data. 
1 Table 1. Parameters for experiments and simulations.

\begin{tabular}{|c|c|c|c|}
\hline Parameters & Values & Parameters & Values \\
\hline $\begin{array}{l}\text { Average flow rate of the } \\
\text { overlying water }(v)\end{array}$ & $12.78 \mathrm{~cm} \mathrm{~s}^{-1}$ & Porosity $(\theta)$ & 0.33 \\
\hline $\begin{array}{l}\text { Average depth of the } \\
\text { overlying water }(H)\end{array}$ & $8.22 \mathrm{~cm}$ & Water density $(\rho)$ & $1000 \mathrm{~kg} \mathrm{~m}^{-3}$ \\
\hline Length of the bedform $(L)$ & $15.2 \mathrm{~cm}$ & $\begin{array}{l}\text { Hydrodynamic viscosity } \\
\text { coefficient }(\mu)\end{array}$ & $0.001 \mathrm{~Pa} \mathrm{~s}$ \\
\hline $\begin{array}{l}\text { Height of top of the } \\
\text { bedforms }\left(H_{b}\right) \text {, Fig. } 1 \mathrm{~b}\end{array}$ & $2 \mathrm{~cm}$ & $\begin{array}{l}\text { Longitudinal dispersivities } \\
\qquad\left(\alpha_{L}\right)\end{array}$ & $0.001 \mathrm{~m}$ \\
\hline $\begin{array}{l}\text { Length of the stoss side of } \\
\text { the bedform }\left(L_{c}\right)\end{array}$ & $11.4 \mathrm{~cm}$ & $\begin{array}{c}\text { Transverse dispersivities } \\
\qquad\left(\alpha_{T}\right)\end{array}$ & $0.0001 \mathrm{~m}$ \\
\hline $\begin{array}{l}\text { Minimum bedform height } \\
\left(H_{s}\right) \text {, Fig. } 1 \mathrm{~b}\end{array}$ & $12.0 \mathrm{~cm}$ & $\begin{array}{l}\text { Effective molecular } \\
\text { diffusion coefficient }\end{array}$ & $10^{-9} \mathrm{~m}^{2} \mathrm{~s}$ \\
\hline Hydraulic conductivity $(K)$ & $8.83 \times 10^{-4} \mathrm{~m} \mathrm{~s}^{-1}$ & $\begin{array}{l}\text { Initial concentration of } \\
\qquad \mathrm{Zn}^{2+}\left(C_{0}\right)\end{array}$ & $2.34 \times 10^{-3} \mathrm{~kg} \mathrm{~m}^{-3}$ \\
\hline $\begin{array}{l}\text { Equilibrium constant for } \\
\text { linear adsorption }\left(K_{a d}\right)\end{array}$ & $0.00142 \mathrm{~m}^{3} \mathrm{~kg}^{-1}$ & $\begin{array}{l}\text { Bulk density of sand bed } \\
\qquad\left(\rho_{b}\right)\end{array}$ & $1.454 \times 10^{3} \mathrm{~kg} \mathrm{~m}^{-3}$ \\
\hline
\end{tabular}





\section{Supporting Information}

\section{Transport of zinc ions in the hyporheic zone: Experiments and simulations}

Guangqiu Jin, Zhongtian Zhang, Ruzhong Li, Chen Chen, Hongwu Tang*, Ling Li, David Andrew Barry

\section{S1 Mesh selection}

In order to choose a suitable mesh for numerical simulation, four meshes with different grid densities were tested (Fig. S1a). The results show that different grid densities have little effect on the concentration variations in the overlying water (Fig. S1b). However, the pore water concentrations differ (Fig. S1c). For Meshes 1 and 2, the concentrations show irregular features, which are not noticeable for Meshes 3 and 4.

Consequently, Mesh 3 was used subsequently.

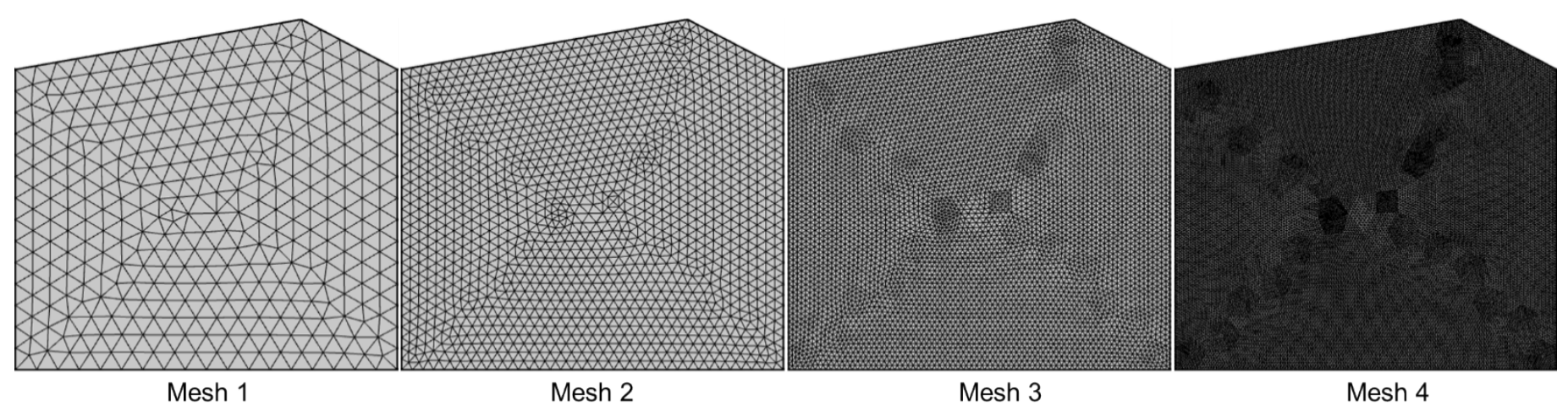

(a)

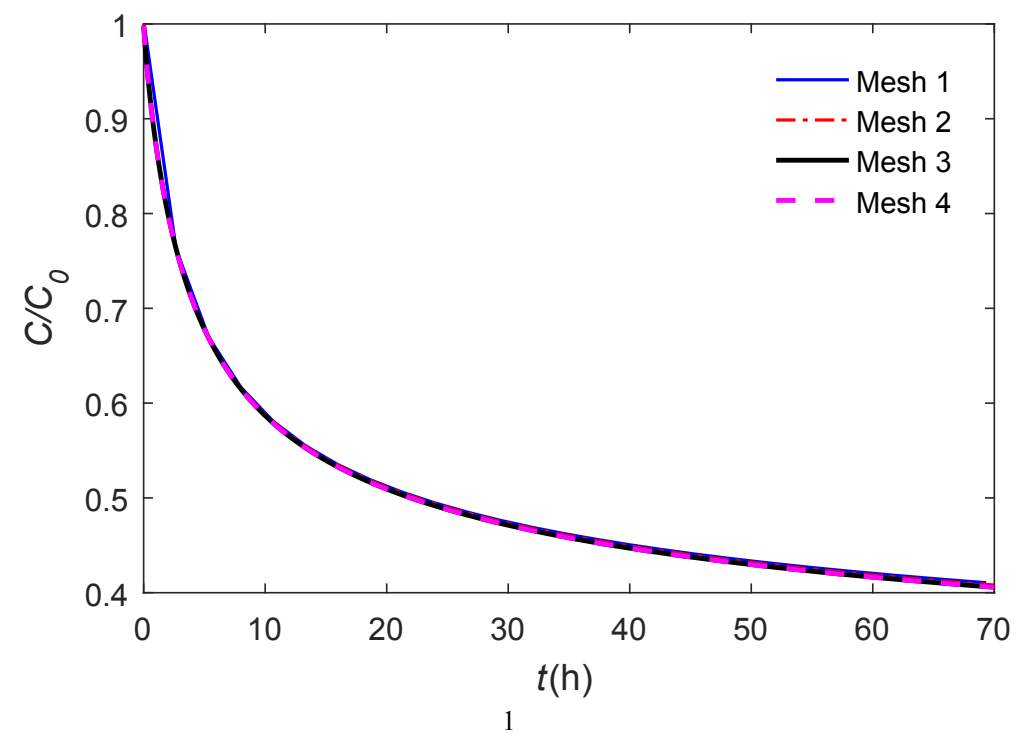


(b)

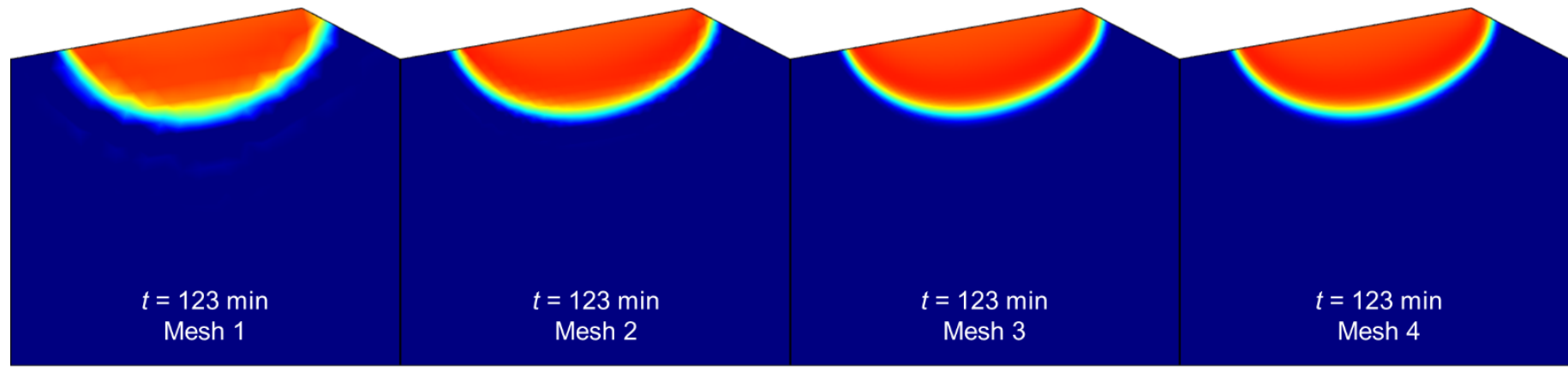

(c)

Fig. S1. (a) Different meshes tested. Meshes 1-4 contained, respectively, 697, 2788, 11152, 44608 grids. Concentration variations in the (b) overlying water and (c) pore water simulated by meshes computed for different meshes. 


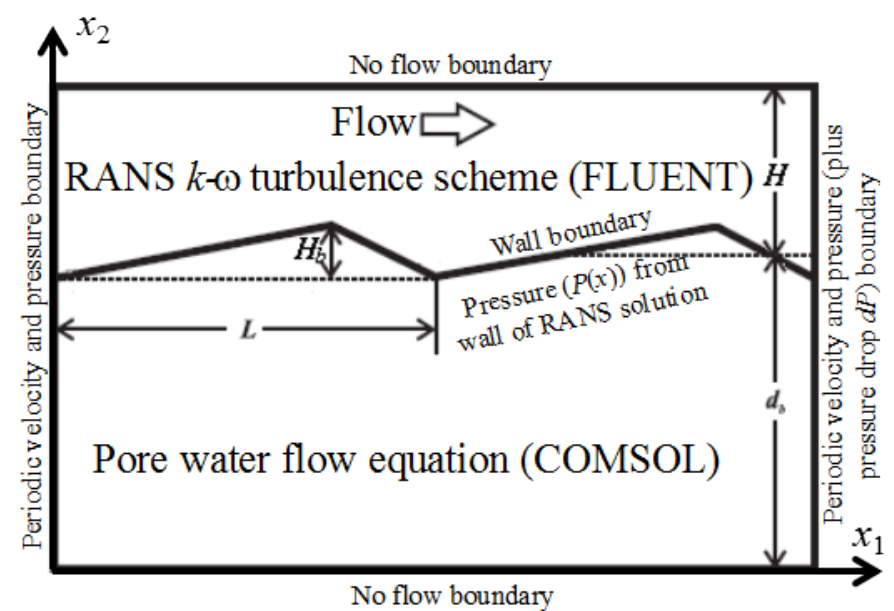

(a)

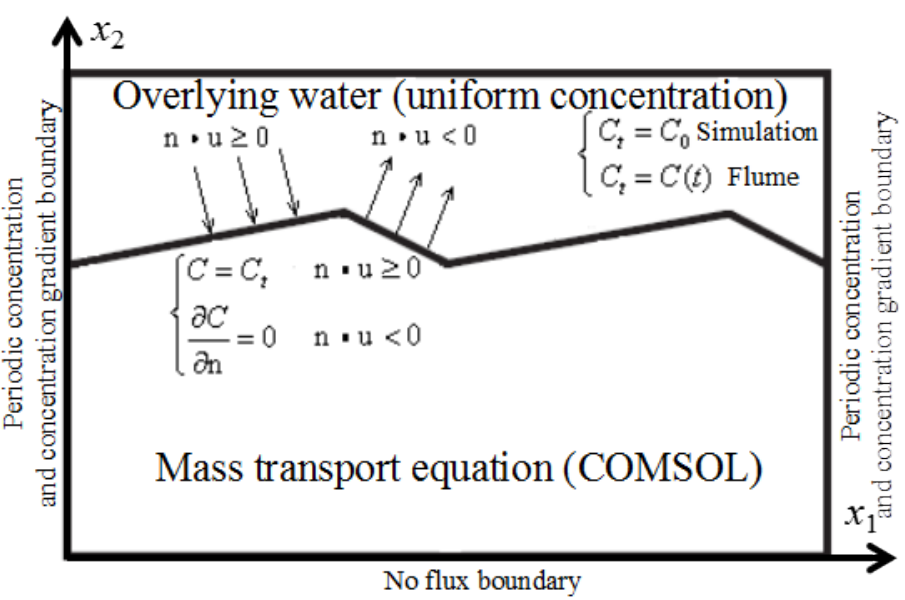

(b)

Fig. S2. Schematic of simulation domain and boundaries. (a) Water flow (overlying water and porewater flow). $L, H, H_{b}$ and $d_{b}$ are the bedform length, average water depth of the overlying water, bedform height and average depth of streambed, respectively. (b) Solute transport. A uniform concentration is assumed in the overlying water. For the solute released from streambed, the total quantity of solute in the overlying water and pore water is assumed to be constant over time in the flume experiment but the concentration in the overlying water is assumed to vary. 

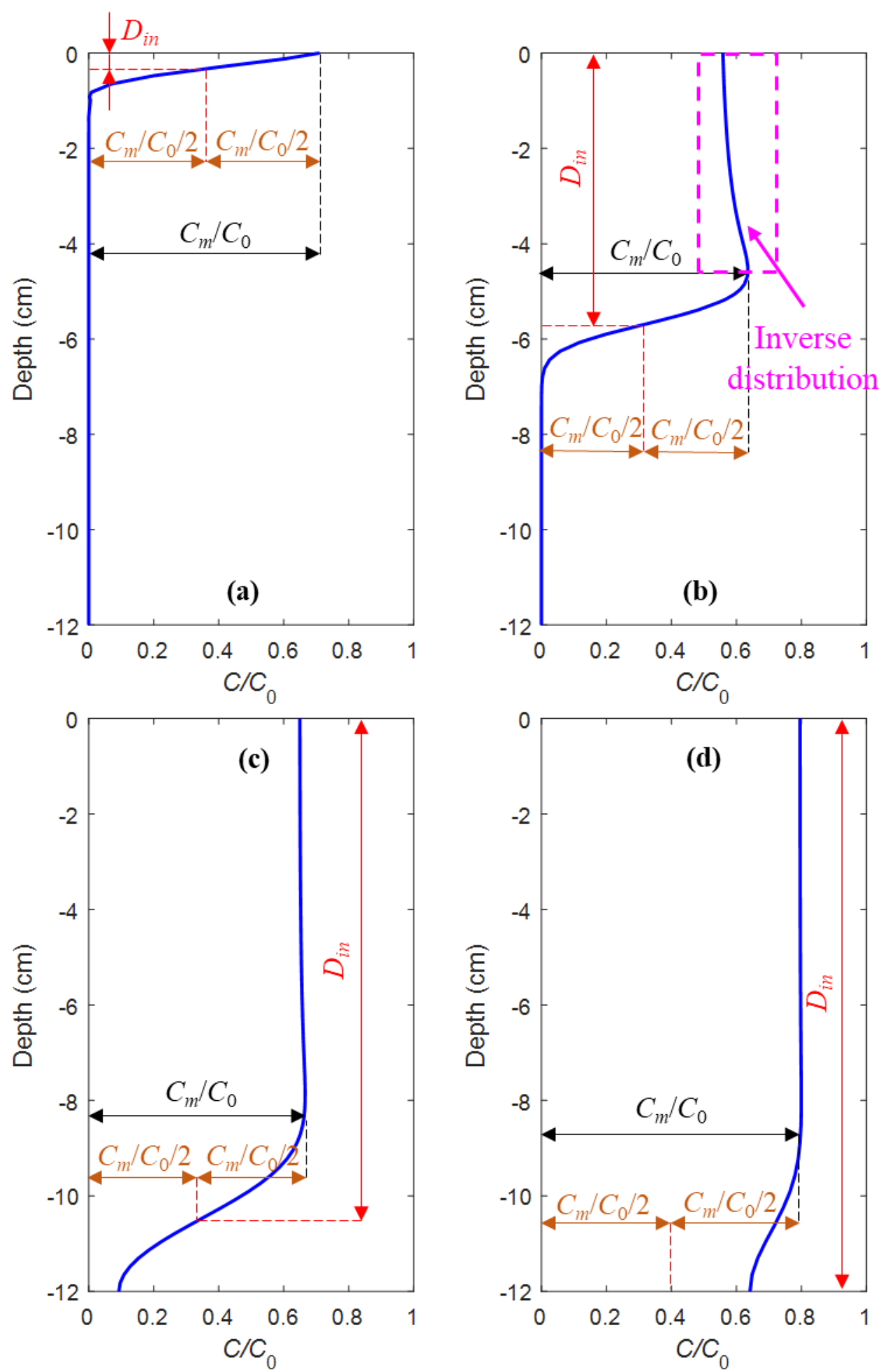

Fig. S3. Sketch for maximum-initial concentration ratio $\left(R_{m}=C_{m} / C_{0}\right)$ and intrusion depth $\left(D_{\text {in }}\right)$ in four different cases, and the curves in the figure do not represent real measured data. (a) The peak concentration for the intrusion line has not reached the profile. (b) The peak concentration for the intrusion line has reached the profile ahead of the front tip. (c) The solute has reached the bottom of the profile but the intrusion depth $\left(D_{i n}\right)$ has not reached the bottom; (d) The intrusion depth $\left(D_{i n}\right)$ has reached the bottom. 


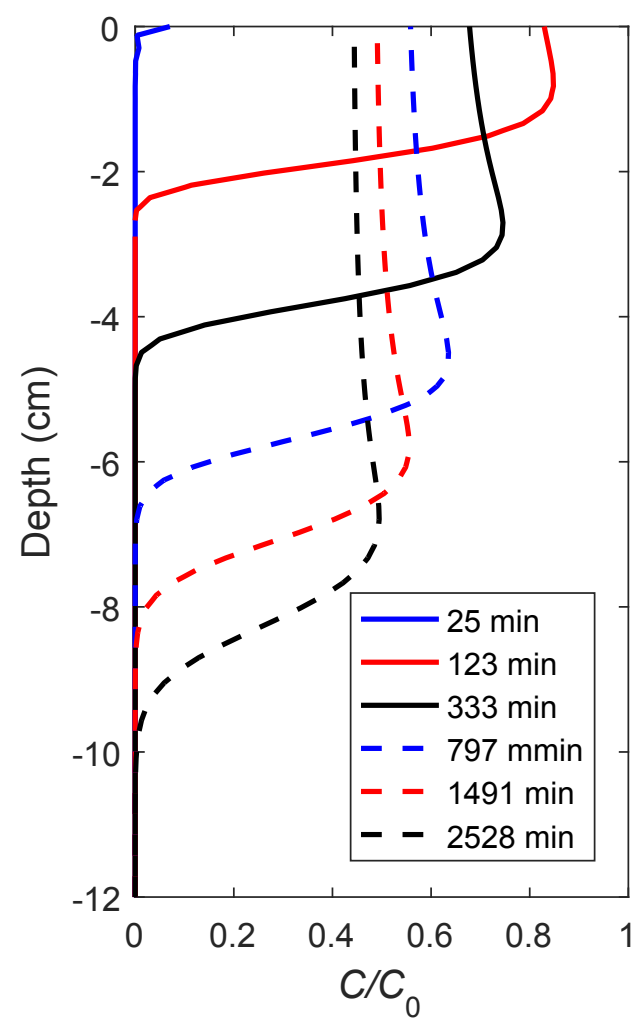

(a)

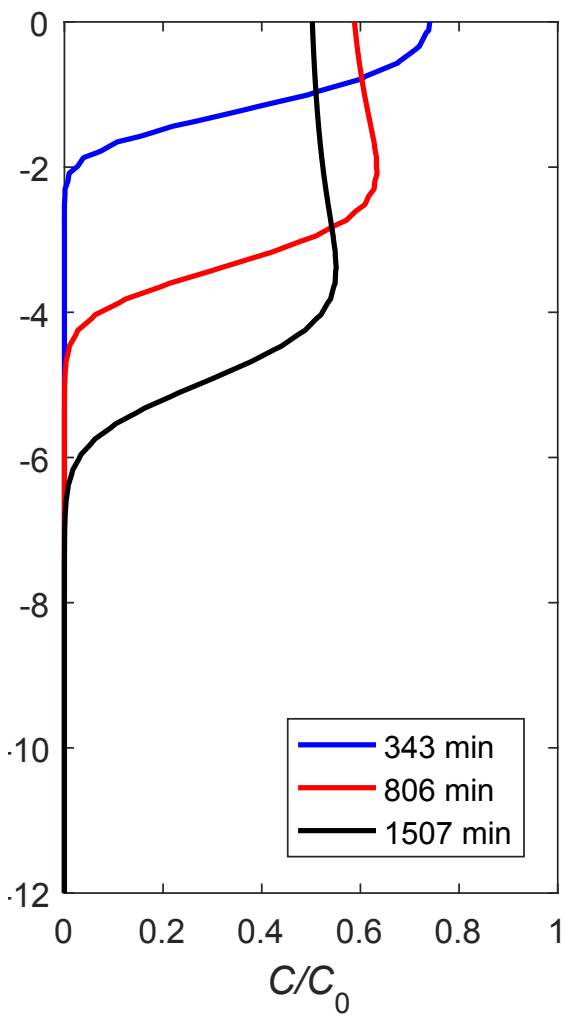

(b)

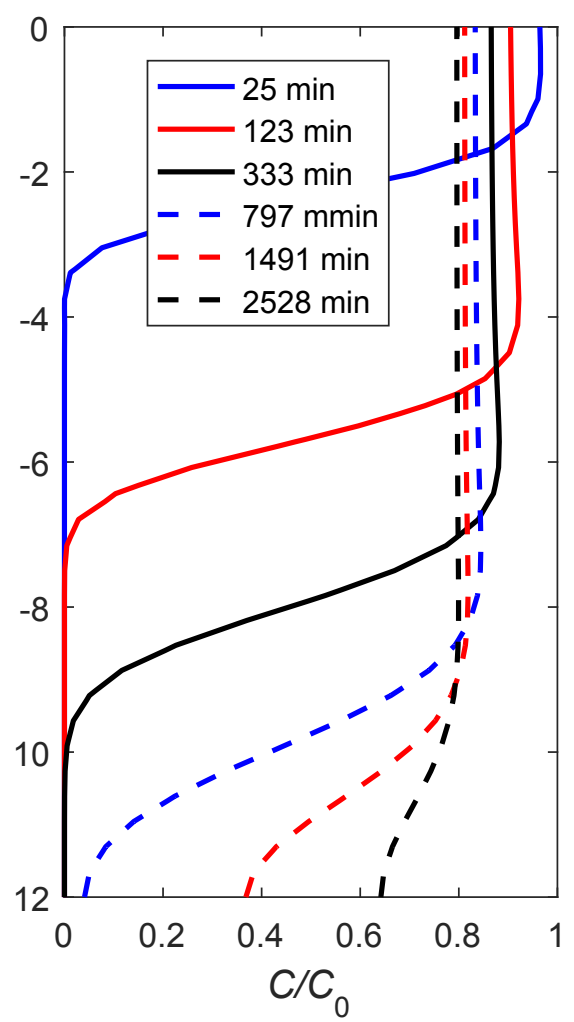

(c)

Fig. S4. Computed concentrations (a) at profile $\mathrm{N} 1$ for $\mathrm{Zn}^{2+}$; (b) at profile $\mathrm{N} 2$ for $\mathrm{Zn}^{2+}$; and (c) at profile N1 for $\mathrm{NaCl}$. 


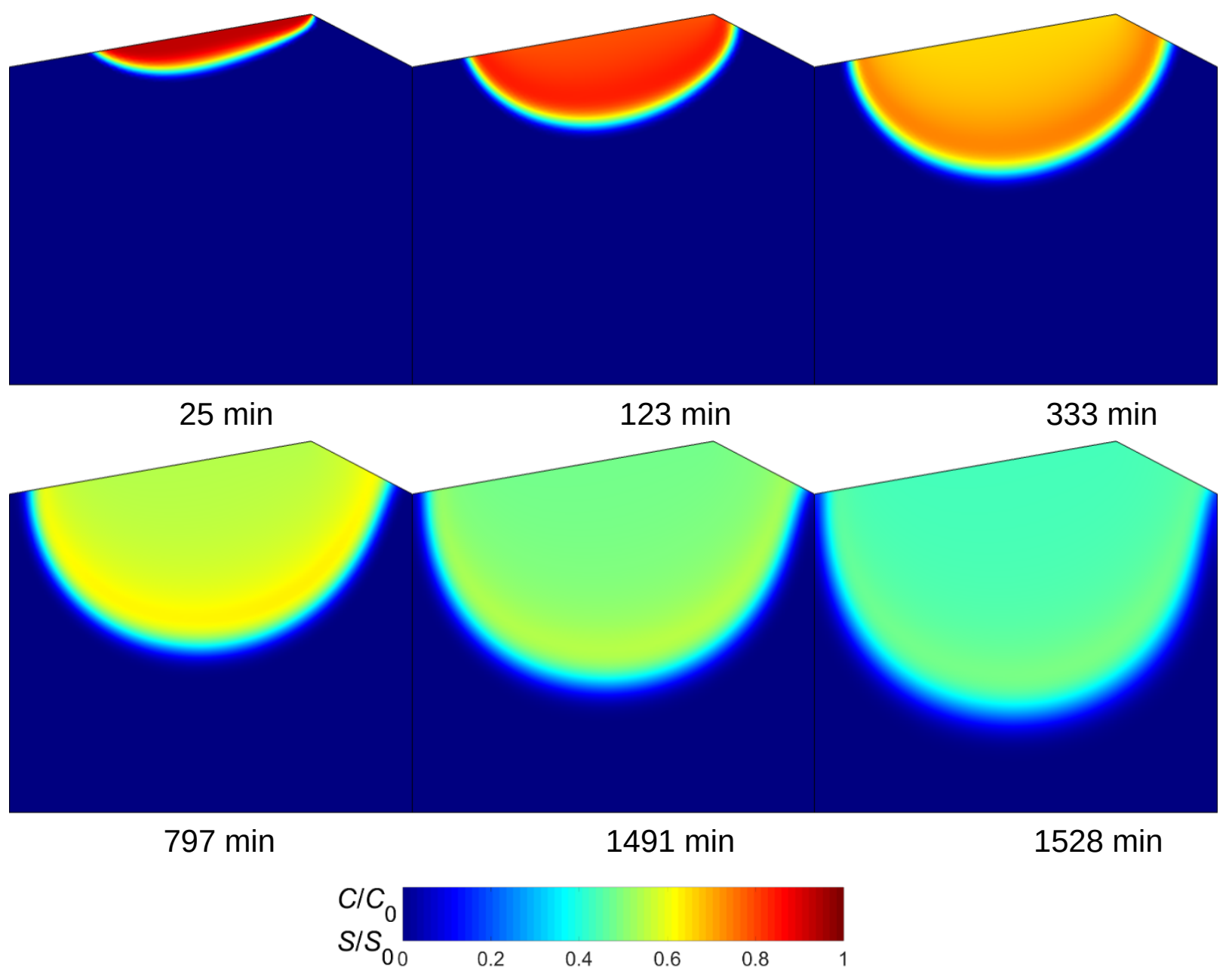

Fig. S5. Normalized concentrations of $\mathrm{Zn}^{2+}$ in pore water and adsorbed at different times. These results are for the linear adsorption isotherm (Eq. 3, 4), so the distributions of $C / C_{0}$ and $S / S_{0}$ are identical. 


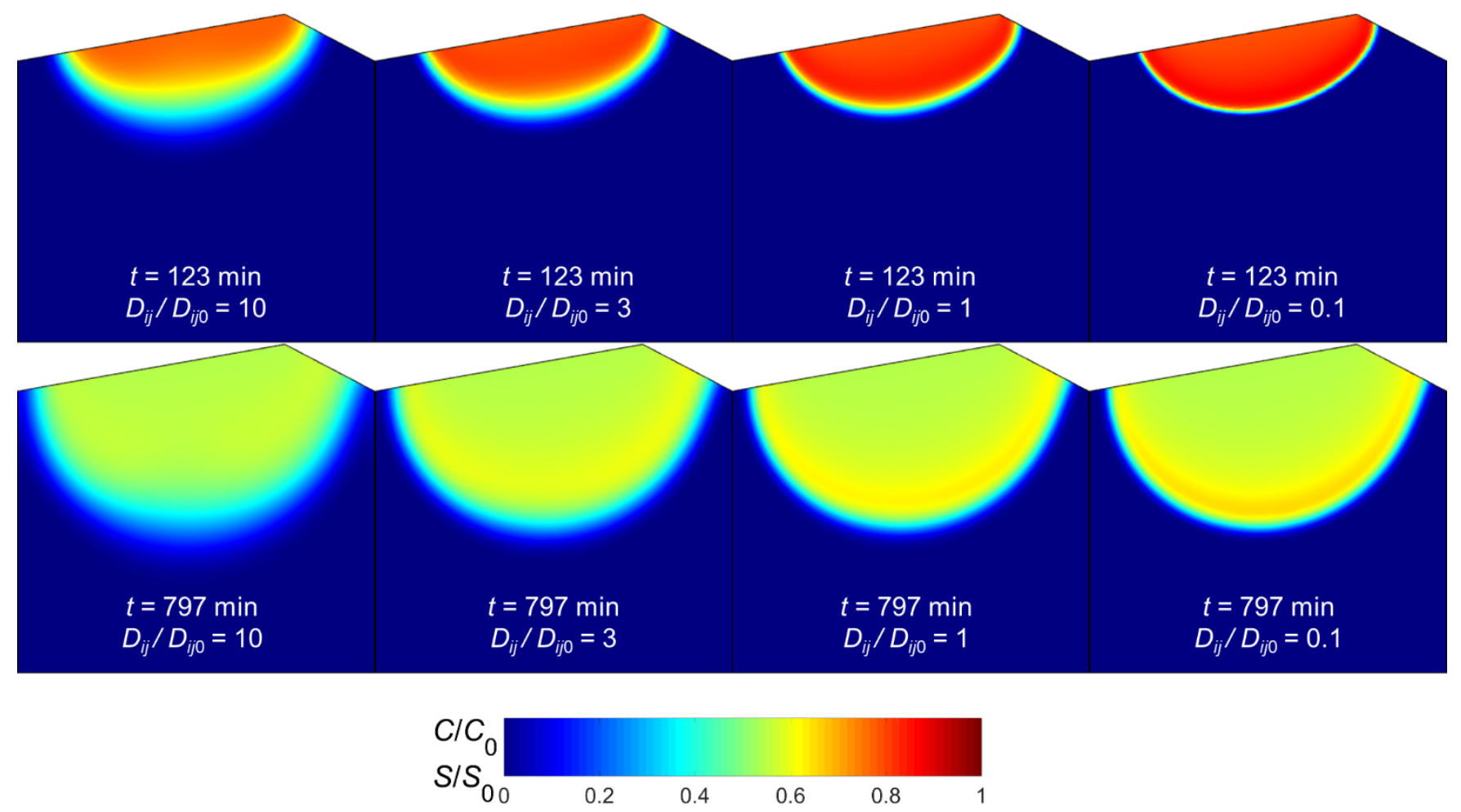

Fig. S6. Normalized concentrations in the bedform for different dispersion coefficients. 


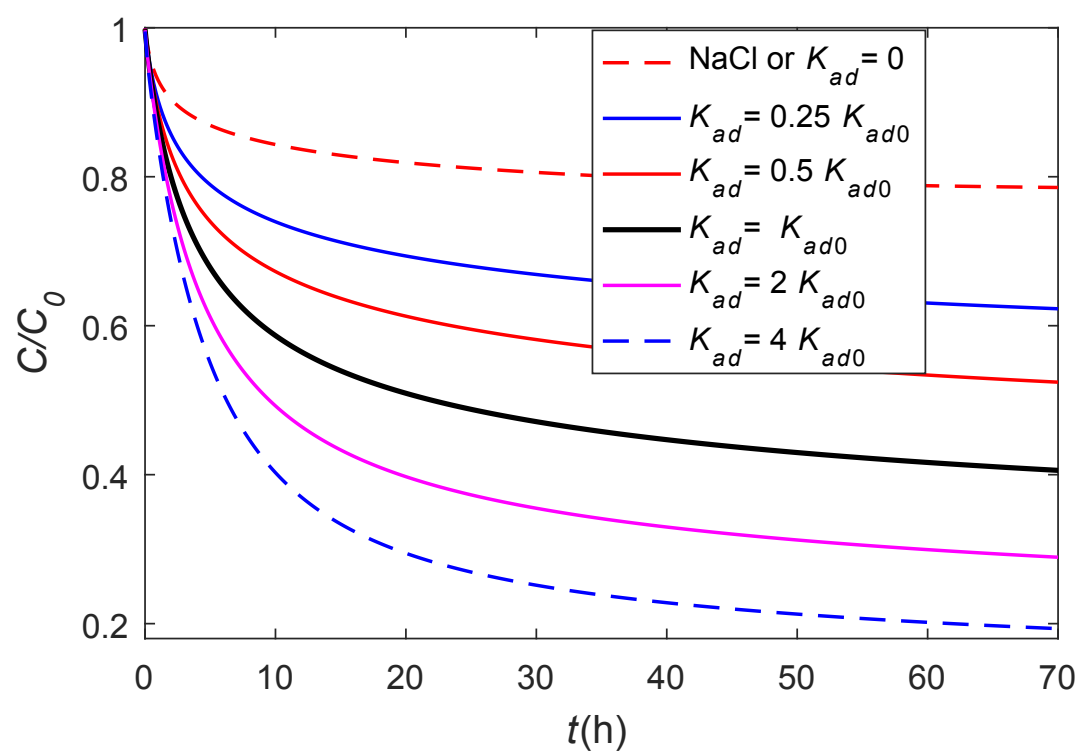

Fig. S7. Normalized concentration evolution in the overland water for different equilibrium constants. 


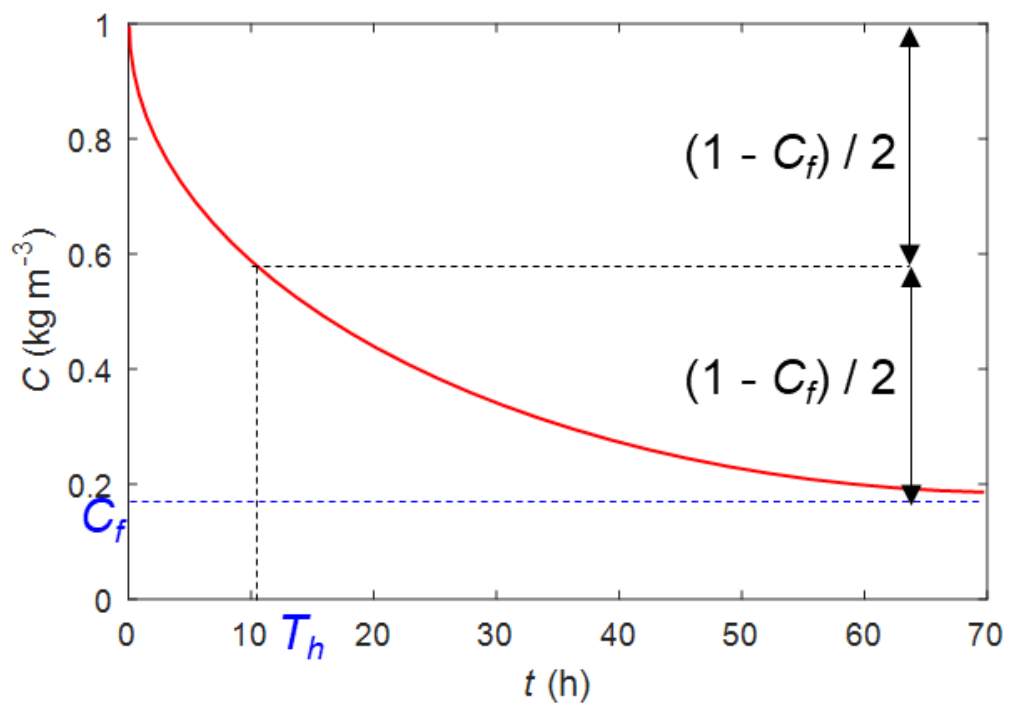

Fig. S8. Definition of final stable concentration $\left(C_{f}\right)$ and half concentration arrival time $\left(T_{h}\right)$. 


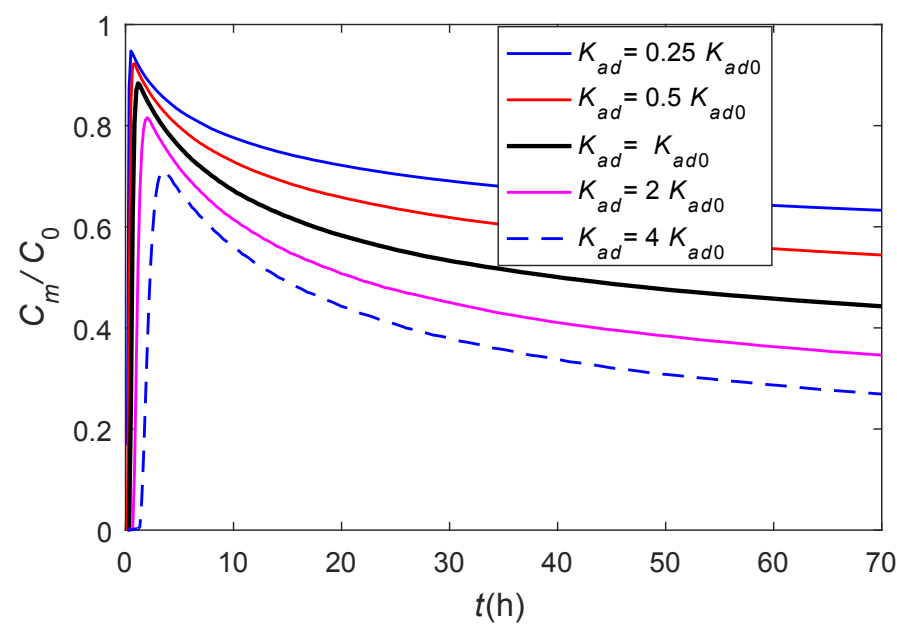

(a)

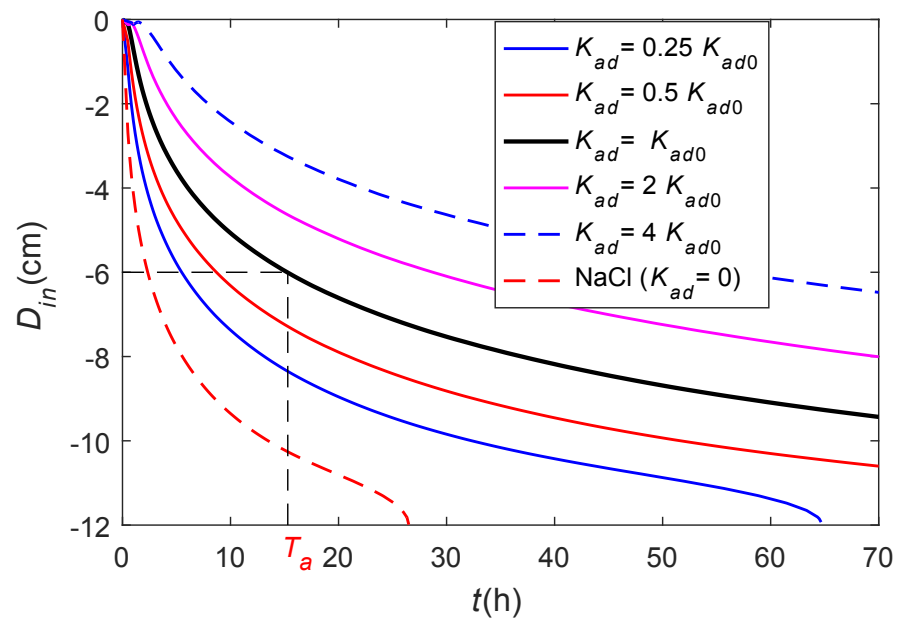

(c)

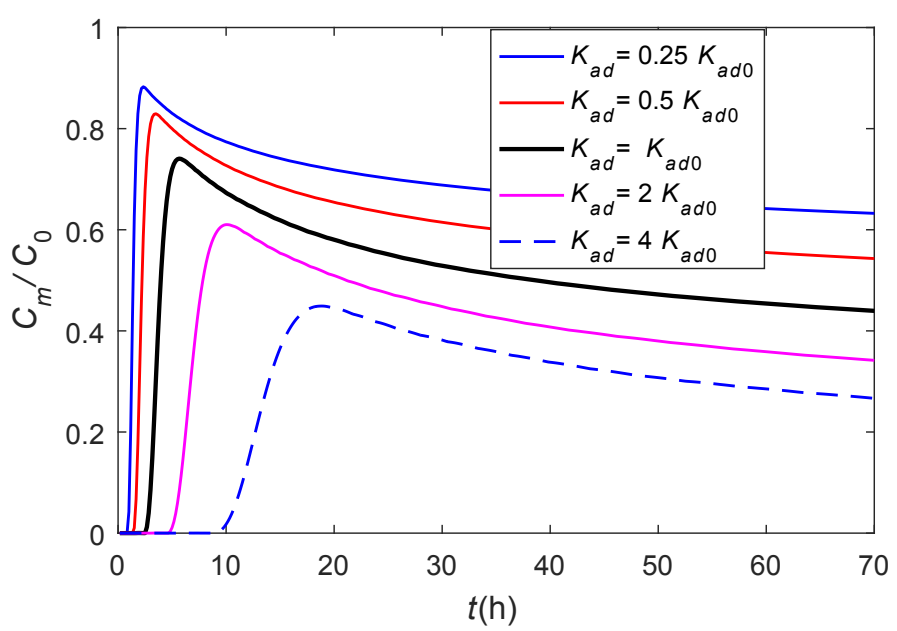

(b)

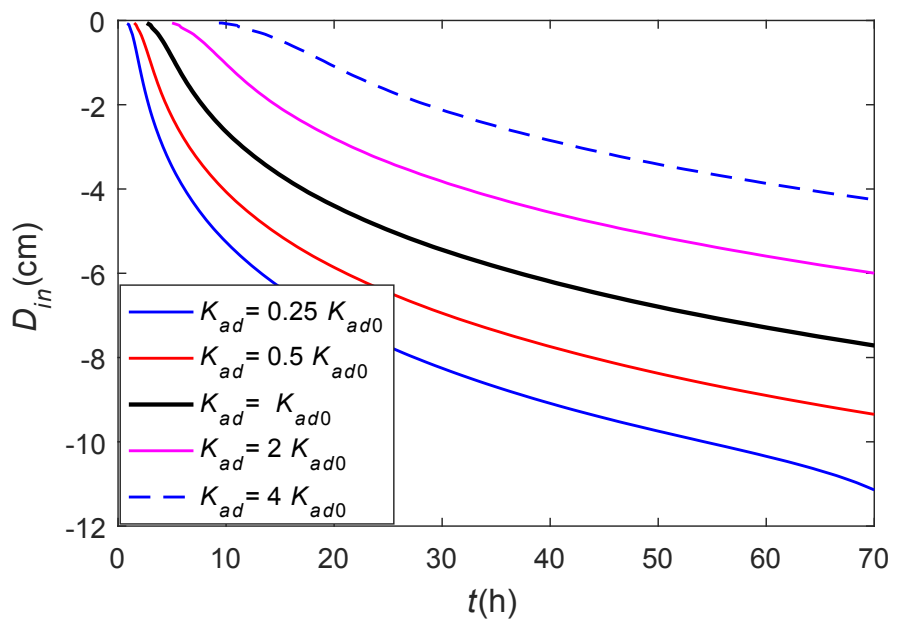

(d)

Fig. S10. Maximum intrusion concentration $\left(C_{m}\right)$ and intrusion depth $\left(D_{i n}\right)$ for different equilibrium constants $\left(K_{a d}\right)$ for different vertical profiles. (a) and (c) N1; (b) and (d) N2. $K_{a d 0}$ is the fitted equilibrium constant for measured data. $T_{a}(\mathrm{~h})$ is the arrival time when the $D_{i n}$ is $-6 \mathrm{~cm}$. 